\title{
Vývoj pozície Medzinárodného maratónu mieru v Košiciach v systéme maratónov sveta a Európy
}

\author{
Vladimír SLAVÍK, Milan KOŠČO
}

\section{Development of the position of the International Peace Marathon in Košice in the system of marathons of the world and Europe}

\begin{abstract}
The aim of the paper is to analyse the position of the marathon in Košice in the system of world and European marathons. We provide an overview of trends of urban circuits of the tracks, the exponential growth of participants, the increase of the women runners and the age diversity of runners, the slowdown of average performances against the background of specific marathons, but at the same time constant improvement of the best performances. Following the example of a marathon in Košice, the paper analyses the geographical aspect of a sporting event in the wider context of other activities of the city of Košice (in recent years the European city in three spheres). We also emphasize comparison of marathons in Košice, Eindhoven and Ljubljana in terms of diversity, number of participants, foreign participation, and sponsors. To achieve this, we evaluate the literature in the field of sports geography, we select and analyse statistical data from event websites and we present them in the form of tables, graphs and maps. We draw attention to the growing importance of marathons as events affecting cities. The results confirm that the long tradition of the event is not enough to compete with much younger marathon runs in the cities of similar size such as Ljubljana and Eindhoven. The importance of the Košice Peace Marathon results from many factors, including long tradition, number of runners and spectators, number of foreign runners, geographical location, marketing, or financial benefits.
\end{abstract}

Keywords: Marathon, Košice, Development of position, World and European marathons, Geographical aspects

\section{Úvod}

Medzinárodné športové akcie prit’ahujú športovcov z celého sveta a vyvolávajú zvýšenú mediálnu pozornost'. Tie najvýznamnejšie, ako olympijské hry či majstrovstvá sveta vo futbale, sledujú miliardy divákov a predstavujú propagáciu hostitel'ských krajín takého dosahu, že ich možno označit' za významné geopolitické aktivity. Podobne ako v geopolitike sa tieto akcie diferencujú podl'a úrovne (významu, mediálneho vplyvu, ekonomického dopadu, participácie a pod.) a pri ich štúdiu je nutné rešpektovat' ich porovnatel'nost'. Tak ako iné, aj športové aktivity tvoria súčast' života regiónu, ktorý Bašovský a Lauko (1980) považujú za zložitý dynamický priestorový systém. V rámci daného regiónu významné športové akcie spoluvytvárajú imidž a branding mesta.

Prvý maratón sa konal v Bostone už v roku 1897, ale až po masovejšom rozšírení siete maratónov od 70. rokov 20. storočia sa postupne rozvinula metodika klasifikácie i komparácie maratónov a rôzne rebríčky, ktoré klasifikujú maratóny podl'a parametrov stanovených športovými asociáciami. Informácie o maratónoch sa tak dostávajú do pozornosti akademického prostredia a je možné skúmat' rôzne dopady športových podujatí na mestá. Ciel'om príspevku je analyzovat' vývoj pozície maratónu v Košiciach v systéme svetových a európskych maratónov a analyzovat' geografické aspekty vybraných maratónov. Hlavná výskumná otázka vyplýva

DOI: https://doi.org/10.33542/GC2020-2-05 
z ciel’a príspevku. Prečo je Medzinárodný maratón mieru (d’alej len MMM) v Košiciach tak vysoko v rankingu IAAF? Prečo je pozícia MMM lepšia ako pozícia maratónov vo väčších metropolách ako Budapešt', Varšava, Viedeň, Krakov, Porto a na strane druhej, prečo mu konkurujú maratóny vo vel'kostne porovnatel'ných mestách ako sú L'ubl'ana či Eindhoven? A zodpovedá športová kvalita MMM tomu poradiu?

Z uvedených otázok vyplývajú hypotézy: (1) MMM v Košiciach je tak vysoko v hodnotení vd'aka dlhej tradícii a imidžu podujatia. (2) Športovou kvalitou patrí maratón skôr k priemerným podujatiam.

\section{Teoretický základ}

Aj ked' sa články s tematikou športu a geografie objavujú sporadicky už viac ako jedno storočie, k rozvoju geografie športu dochádza až v posledných desat'ročiach. Významnú zásluhu na tom majú aktivity dvoch autorov, ktorých môžeme považovat' za skutočných zakladatel'ov geografie športu. Sú nimi John Rooney v Amerike a John Bale v Európe. Geografia športu je ,špecifickou geografickou subdisciplínou zaoberajúcou sa štúdiom športových aktivít prebiehajúcich na zemskom povrchu a priestorovou distribúciou športu a jeho zmenami $v$ čase; meniaceho sa charakteru športového prostredia a jeho vzájomného vzt'ahu $s$ účastníkmi športových aktivít; vytvárania návrhov na priestorové zmeny v rámci športového prostredia." (Bale 2003, p. 15). Ked’že ide o pomerne mladú špecializáciu, ktorá sa formuje a rozvíja v období tematickej fragmentácie geografie a postmoderných prístupov, je pre ňu charakteristická rozmanitá paleta tém a metód spracovania. Relatívne obmedzený počet autorov, ktorí sa problematike venujú spôsobuje, že nie všetky témy, ktorými by sa geografia športu mohla zaoberat', sú publikačne pokryté. V rámci výskumu doposial' dominujú najpopulárnejšie športy (futbal v celosvetovom meradle), ekonomicky najatraktívnejšie športy, ale aj také športové podujatia, ktoré môžeme považovat' za geografické z podstaty, ako cyklistika, treking a pod. Atletika síce patrí vd’aka behu ako najprirodzenejšiemu športu vôbec k najstarším športom, no odborných prác zaoberajúcich sa atletickými disciplínami z geografického hl'adiska nie je vel'a, väčšina z nich sa koncentruje na behy. Práve bežecké disciplíny (bežci a trate) indikujú isté geografické súvislosti. Mnohým témam však geografia športu nevenuje dostatočnú pozornost'. To je aj prípad maratónov.

Zmienky o športových podujatiach z geografického hl'adiska sa objavujú už v 19. storočí. V roku 1879 sa Réclus v diele Géographie Universelle zaoberal okrem iného kriketom. Hilderbrand v roku 1919 publikoval článok The Geography of Games. Lehrman (1940) zverejnil štúdiu pod názvom The geographical origin of Professional baseball players. Rooney (1969) skúmal geografické rozdiely pôvodu prvotriednych futbalistov v USA a ich migráciu od strednej až po vysokú školu. Mnohí d’alší autori nasledovali články Rooneyho a publikovali príspevky použitím podobných metód skúmania, napr. Bale (1982, 1990), Augustin (1995), Ravenel (1998). Walterspieler (1982) publikoval článok o umiestnení futbalových tímov v Lotrinsku a koreláciu medzi úrovňou tímov, obyvatel'ov miest a ich ekonomickej aktivity. Bale vydal publikáciu Sport's Geography (1989, 2003), ktorá je míl'nikom vo vývoji geografie športu. Maguire (2005) prezentuje globalizáciu športu. Wise a Kohe (2018) riešili otázku dopadu koncentrácie športových lokalít na spoločnost'. Cidell (2017) riešil otázku cestných behov.

Geografia športu sa v slovenskej geografii doteraz prezentovala len sporadickými príspevkami. Zubriczký (1996) konštatoval, že šport je fenoménom, ktorý má mnohé dopady, vrátane regionálnych, odráža ekonomické a spoločenské postavenie regiónu. Geografickými aspektami bežeckých pretekov sa prvý začal zaoberat' Slavík. Spoločne s Mičietovou analyzovali cezhraničný beh Skalica - Hodonín (Slavík a Mičietová 2002) v kontexte cezhraničnej spolupráce. Problematikou športových podujatí v urbánnom priestore sa zaoberal Kováč (2009). Zvýšený záujem o témy geografie športu registrujeme v poslednej dekáde. Horvát (2011) zhodnotil vývoj bežeckých pretekov v Bratislave a Tužinčin (2013) maratóny vo svetových metropolách. Bačík a Klobučník (2013, 2017, spolu s Mignot 2019) prezentovali Tour de France ako významnú športovú udalost's celosvetovým dosahom, analyzovali viaceré priestorové aspekty v dlhých časových radoch pomocou pokročilejších GIS technológií. Vybrané aspekty košického maratónu 
predstavili Slavík a Koščo na konferenciách v Danišovciach (Slavík a Koščo 2015, 2018), Bratislave (Slavík a Koščo 2018) a Lochówe (Pol'sko) (2019). Klobučník, Plešivčák a Vrábel' (2019) skúmali vzt’ah športových výkonov a vybraných ekonomických aspektov futbalových klubov v regiónoch Európskej únie. Z českej geografie možno uviest’ ako reprezentantov tohto zamerania Tomeša $(2011,2012)$ a Slepičkovú a Slepičku (2012).

Tak ako sa obchod, ekonomika a kultúra globalizujú, tak sa globalizuje aj šport. Vel'ké mestá sa v súčasnosti vyznačujú dynamikou vnútornej reštrukturalizácie, ktorá je významne formovaná internacionalizáciou a globalizáciou a ich vzájomnou konkurenciou (Korec 2013). Významným prejavom globalizácie je migrácia športovcov. „Šport a presnejšie domáci šport je hodný pozornosti geografa, pretože má ekonomickú významnost', sociálne dôsledky, schopnost' vykazovat' určité kultúrne korene, prispievajúce k pochopeniu využívania mestskej plochy a celkového priestoru sídiel.“ (Burley 1966, p. 55). „Pri hodnotení športu $z$ hl'adiska úspešnosti a geografie nejde len o vítazstvo, tituly a rekordy, ale aj o spomínaný vplyv športu na kvalitu života a zdravie obyvatel'ov a nepriamo i na ekonomickú efektivitu spoločnosti." (Tomeš 2011, p. 20).

Maratóny síce nepatria medzi podujatia s najvyššou mierou sledovanosti, ale ich význam spočíva v tom, že ide o masovú akciu, ktorej sa zúčastňujú tisíce športovcov, profesionálov i amatérov. Maratóny organizované v mestách majú v rámci športových podujatí špecifické postavenie. „Maratón je jediná sútaž, v ktorej je masám dovolené byt'v rovnakom čase na rovnakej trati ako svetová špička." (Jones a James 2012, p. 12). Young (2016) zdôrazňuje sociálny aspekt maratónskych behov v mestských okruhoch. Priemerné časy sú pomalšie, ale elitné špičky sa zlepšujú a stúpa aj priemerný vek bežcov.

Metodika príspevku je založená na selekcii, analýze a syntéze dát získaných z dostupných oficiálnych štatistík. $\mathrm{V}$ posledných rokoch databázy maratónov poskytujú všetky potrebné údaje o bežcoch, ale ekonomické údaje je stále pomerne komplikované získat'. Údaje o počtoch bežcov niekedy skresl'ujú aj počty účastníkov v subdisciplínach maratónov, ktoré organizátori pridávajú do štatistiky podujatia z ekonomických, charitatívnych, marketingových dôvodov (Koščo 2018). Pre analýzu vývoja vybraných parametrov maratónov boli použité indexy dynamiky rastu, demografické ukazovatele (podiel mužov a žien, vít’azi podl'a štátov, počet bežcov na 1000 obyvatel'ov, medián a modus veku a pod.) a štatistické metódy (korelačná analýza, variačný koeficient). Hodnotené ukazovatele a ich vývojové tendencie boli postupne vyhodnocované na základe tabuliek, grafov a obrázkov, limitovaná kapacita príspevku nám umožňuje prezentovat' len vybrané $\mathrm{z}$ nich.

Analýzam dial'kových behov vrátane maratónov sa venujú len niektoré športové magazíny, napr. www.impactmarathon.com/in-the-media, www.runnersworld.com a špecializované webové stránky (https://arrs.run, http://iaaf.com, http://aims-worldrunning.org). Hodnotenia behov z hl’adiska geografie sú úplne výnimočné (Cidell 2017, Qviström 2017) a týkajú sa predovšetkým dial'kových behov v teréne.

\section{Kritériá hodnotenia maratónov}

Skôr ako sa ustálili všeobecne uznávané kritériá hodnotenia maratónov, používali sa hodnotenia podl'a roku založenia, počtu zúčastnených krajín, počtu bežcov, neskôr aj podielu mužov a žien, výškového profilu trate a pod.

Ak má byt' maratón uznaný Medzinárodnou asociáciou atletických federácií (International Association of Athletics Federation, d'alej IAAF) a zapísaný do jej kalendára, musí splńnat' niekol'ko kritérií (nie všetky maratóny sú zapísané v databáze IAAF, reálna databáza maratónov nielen v Európe má vyššiu mohutnost'). Základ pre metódu hodnotenia podl'a IAAF bol vyvinutý v roku 1979 a postupne sa zdokonal'oval. Medzi najdôležitejšie patria počet bežcov maratónu (okrem subdisciplín, ktoré v súčasnosti zvyčajne dopín̆ajú hlavnú akciu, čím sa zvyšuje atraktivita a aj celkový počet účastníkov), počet zastúpených štátov, rešpektovanie právnych noriem, živé vysielanie prostredníctvom televízie alebo online streamovanie. Z hl'adiska kvality bežcov sa vyžaduje účast' bežcov $\mathrm{z}$ aspoň piatich štátov s dosiahnutým časom bežcov 
lepším ako IAAF limity pre konkrétne obdobie. Bežat' musí aspoň pät' mužských a pät’ ženských elitných športovcov. Za takých sú považovaní tí, ktorých najlepší osobný výkon v rámci trojročného obdobia pred príslušnou udalost'ou dosiahol štandard určený IAAF. Ku kritériám, na základe ktorých sa hodnotí postavenie maratónu, patrí aj výška odmeny pre vít’aza, obsah a úplnost' webovej stránky podujatia, organizovanie tlačových konferencií, špecifikovaný počet vykonaných dopingových testov, primerané lekárske vybavenie na počet bežcov, počet staníc občerstvenia. Trat' musí byt' certifikovaná a uzavretá pre premávku, spôsob merania času sa vykonáva podl'a štandardu s plným elektronickým časovaním. Preteky musia byt' organizované tak, aby minimalizovali ekologické škody a zohl'adňovali bezpečnostné opatrenia. Elitné hodnotenia maratónov sa udel'ujú aj na základe záväzku organizátora k pokroku v športe a konkrétnych krokov v globálnom boji proti dopingu. Vývoj kritérií hodnotenia maratónov je dynamickým systémom, ktorý reflektuje okolnosti doby, vývoja behu, vývoj bežeckých časov i geopolitické hl'adisko.

\section{Výber najvýznamnejších maratónov a ich porovnatel'nost'}

Najvýznamnejšie maratóny sveta sú zastrešené dvomi medzinárodnými inštitúciami. Tie reprezentujú International Association of Athletics Federation (IAAF) a Association of International Marathons and Distance Races (AIMS), ktorej členmi sú aj maratóny v Bratislave a Košiciach. Pre sériu šiestich najprestížnejších maratónov sveta sa používa termín „World marathon majors“. Tie sa konajú v metropolách Boston, Chicago, New York, Berlín, Londýn, Tokio (obr. 1). Ide o maratóny na severnej pologuli približne v rovnakých geografických šírkach.

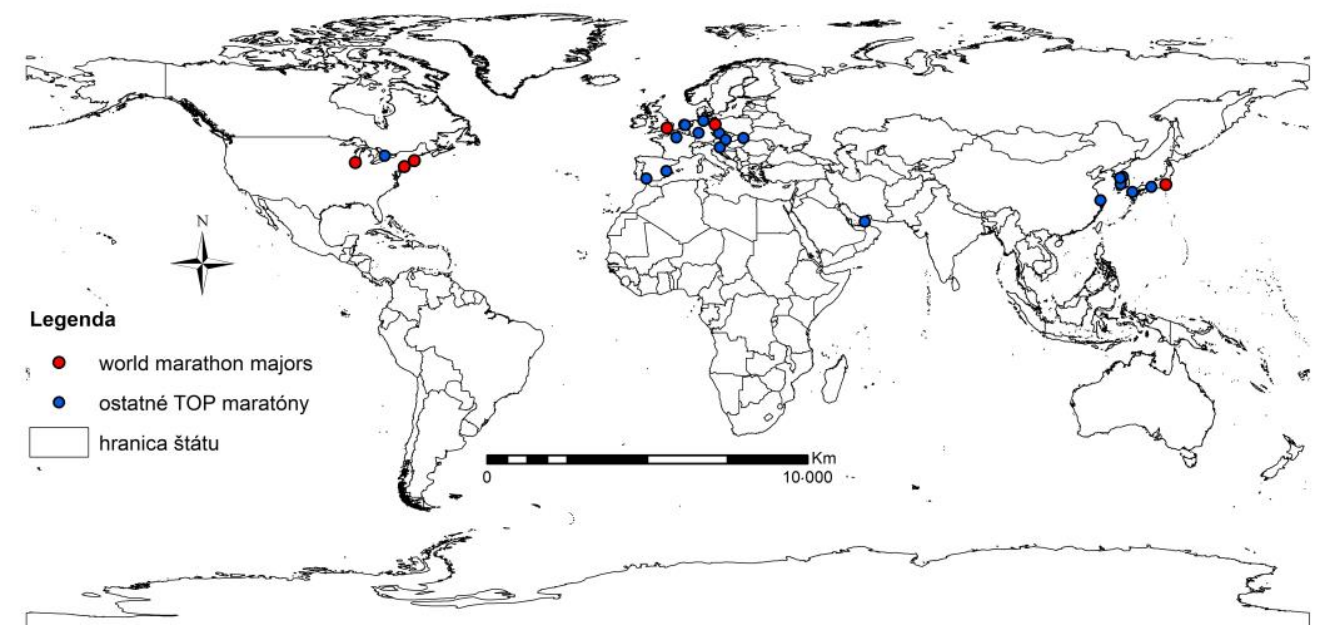

Obr. 1. Najvýznamnejšich 25 maratónov sveta podl'a IAAF; Zdroj: World Athletics (2019)

Postavenie týchto metropol v rámci športu dokumentuje Global Sports Impact Cities Index, kde v rokoch 2012 - 2015 dominovali Tokio (1. miesto), Londýn (2. miesto), no v roku 2019 Londýn poklesol na 6. a Berlín na 23. priečku. Praha dosiahla 36. miesto a Košice zaujali 110. miesto pred Chicagom (129. miesto), Bostonom (150. miesto). Maratón v Košiciach patrí v súčasnosti medzi významné európske atletické sút’aže aj v kontexte globalizácie športových podujatí. MMM sa umiestnil $\mathrm{v}$ roku $2018 \mathrm{v}$ rámci európskeho poradia na 12. mieste a v rámci celosvetového rebríčka na 24. mieste (Slavík a Koščo 2018). V roku 2019 vo svetovom hodnotení klesol na 59. miesto (v Európe na 21. miesto). Konkurenciou sú mu napríklad aj maratóny v Eindhovene či L'ubl'ane. 


\section{Maratóny porovnatel'né s MMM v Košiciach}

MMM v Košiciach z hl'adiska organizácie, počtu obyvatel'ov mesta, počtu bežcov a d'alších kritérií je možné porovnávat's maratónmi v mestách, ktoré majú rádovo približne rovnaký počet obyvatel'ov, pričom predstavujú konkurenciu pre MMM. Prioritne ide o mestá Eindhoven a Lubl'ana, ktoré sa umiestňujú v rebríčku IAAF relatívne vysoko (obr. 2).

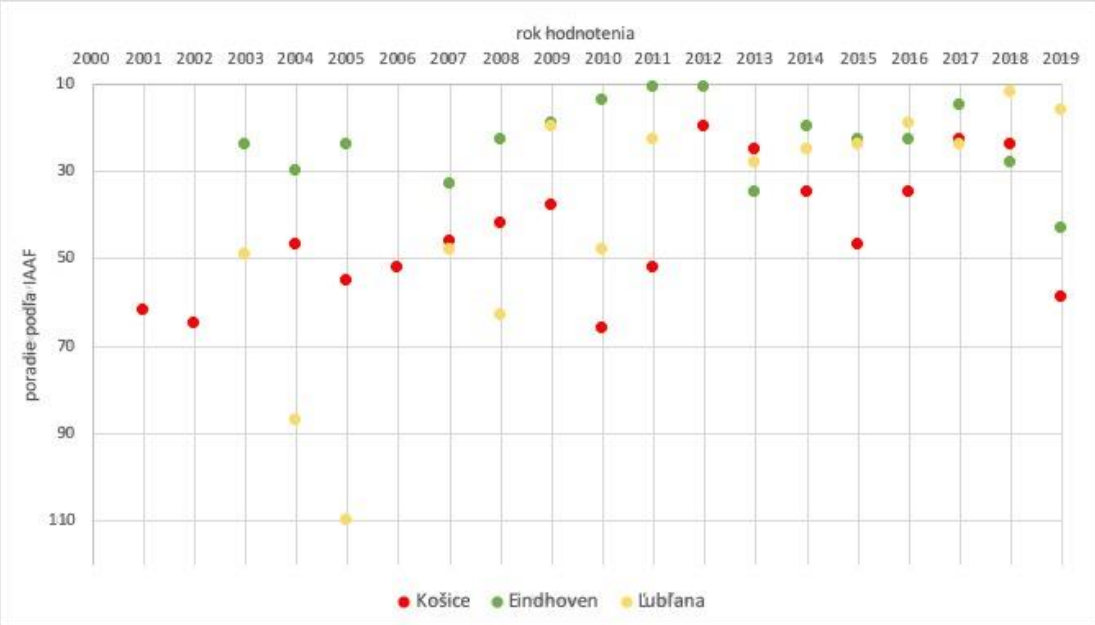

Obr. 2. Vývoj pozície maratónov v Košiciach, Eindhovene a Lubl'ane podl'a IAAF v rokoch 2001 - 2019; Zdroj: World Athletics (2019)

Ďalej je relevantná komparácia MMM s maratónmi v metropolách susedných štátov (Praha, Budapešt', Viedeň, Varšava), prípadne s maratónmi, ktoré síce nepatria ku špičke, avšak majú svoje stabilné miesto v hodnotení IAAF (Krakov, Padova, Lausanne, Hannover, Terst, Porto). Pri hodnotení pozície v rebríčku IAAF sledujeme fluktuáciu rankingu v čase. Napríklad pozícia maratónu v Budapešti (183. miesto v roku 2019) je výrazne horšia ako pozícia maratónu v Košiciach. Na druhej strane maratón v Prahe (jeden z najkozmopolitnejších) si za krátku dížku trvania (od roku 1995) vybudoval vysokú pozíciu (7. miesto v roku 2016) (tab. 1).

Tab. 1. Vývoj poradia vybraných maratónov podl'a IAAF v rokoch 2004-2019

\begin{tabular}{l|rrrrrrrrrrrrrr}
\hline lokalita/rok & 2004 & 2005 & 2007 & 2009 & 2010 & 2011 & 2012 & 2013 & 2014 & 2015 & 2016 & 2017 & 2018 & $\mathbf{2 0 1 9}$ \\
\hline Košice & 47 & 55 & 46 & 38 & 66 & 52 & 20 & 25 & 35 & 47 & 35 & 23 & 24 & 59 \\
Eindhoven & 30 & 24 & 33 & 19 & 14 & 11 & 11 & 35 & 20 & 23 & 23 & 15 & 28 & 43 \\
L'ubl'ana & 87 & 110 & 48 & 20 & 48 & 23 & - & 28 & 25 & 24 & 19 & 24 & 12 & 16 \\
Praha & 20 & 18 & 41 & 18 & 11 & 13 & 12 & 21 & - & 12 & 7 & 11 & 16 & 13 \\
Budapešt' & 118 & 135 & 142 & 172 & 155 & 242 & 167 & 169 & 220 & 185 & 180 & 142 & 156 & 183 \\
Varšava & 102 & 48 & 62 & 117 & 61 & 50 & 80 & 29 & 21 & 20 & 41 & 41 & 39 & 47 \\
Viedeň & 16 & 44 & 24 & 22 & 23 & 16 & 13 & 20 & 19 & 32 & 14 & 13 & 20 & 21 \\
Krakov & - & 103 & 86 & 84 & 115 & 54 & 69 & 202 & 142 & 131 & 67 & 86 & 64 & 84 \\
Graz & - & 57 & - & 103 & 112 & - & 87 & - & 179 & - & - & - & 153 & - \\
Padova & 25 & 8 & 42 & 37 & 83 & 34 & 36 & 66 & - & 114 & 116 & 100 & 78 & 89 \\
Lausanne & 73 & - & - & - & 208 & 172 & - & 204 & 189 & 147 & 149 & 159 & 149 & 167 \\
Hannover & 51 & - & - & 55 & 28 & 27 & 24 & 33 & 37 & 28 & 42 & 38 & - & 46 \\
Terst & 58 & - & 52 & - & 218 & - & 102 & - & 172 & 157 & - & - & - & - \\
Porto & - & - & - & 53 & 107 & 103 & 73 & 70 & 82 & 149 & 47 & 84 & 46 & 100 \\
\hline
\end{tabular}

Zdroj: World Athletics (2019); Vysvetlivky: - maratón nebol v konkrétnom roku $v$ databáze/hodnotení IAAF 
V rámci porovnatel’ných miest výrazne v hodnotení poklesol maratón v Grazi, ktorý sa už neobjavuje na prvých 200 miestach v hodnotení IAAF. Stabilne sa v rebríčkoch (v hodnotení síce na horších pozíciách) objavujú maratóny v Lausanne, Padove, Porte. Výraznejšie výkyvy v medziročnom hodnotení podl'a IAAF, či už ide o zlepšenie alebo zhoršenie pozície, pozorujeme v prípade L'ubl’any, Košíc, Varšavy, Prahy a Viedne. Relatívne stabilnú pozíciu majú Eindhoven, Lausanne a Hannover.

\section{Vývoj pozície Košíc podl’a najěastejšie používaných kritérií maratónov}

V súlade s tendenciou zakladania nových maratónov, ekonomickým benefitom pre vít'azov, zmenou štruktúry bežcov, je aj maratón v Košiciach nútený reagovat' na tieto skutočnosti. Pri hodnotení maratónov sa najčastejšie používajú nasledovné kritériá: rok založenia, počet účastníkov, podiel pohlaví, zastúpenie štátov, profil trate, ekonomický dopad a pod.

\section{Kritérium roku založenia}

Medzinárodný maratón mieru v Košiciach bol založený v roku 1924. Je štvrtým najstarším na svete po maratóne v Bostone, Yonkers (predmestie New Yorku) a Polytechnic/Windsor maratóne v Chiswicku vo Vel'kej Británii (tento bol založený v roku 1909, je teda síce starší, ale jeho fungovanie nebolo kontinuálne, poslednýkrát sa uskutočnil v roku 1996). Podl’a početnosti konania je teda maratón v Košiciach tretí najstarší (tab. 2).

Maratón v Košiciach ako najstarší súvisle fungujúci maratón v Európe zaujíma v tomto ukazovateli exkluzívne postavenie (tab. 2). Výraznejší nárast počtu maratónov začína od 70. rokov 20. storočia (tab. 3), kedy sa objavujú maratóny v Aténach, Berlíne, Göteborgu, Amsterdame a v Paríži. Význam maratónu v Košiciach bol v 60. rokoch 20. storočia väčší ako v súčasnosti, čo potvrdzuje aj vít’azstvo Abebe Bikilu v roku 1961, čerstvého vít'aza OH v Ríme (1960) alebo vít’azstvo Leonarda Edelena v roku 1963. V tom čase patril maratón v Košiciach k najlepším 5 maratónom na svete.

Tab. 2. 15 najstarších maratónov vo svete podl’a počtu rokov konania do roku 2019

\begin{tabular}{r|llllll}
\hline P. & Mesto/lokalita & Štát & $\begin{array}{l}\text { Mesiac } \\
\text { konania }\end{array}$ & $\begin{array}{l}\text { Rok } \\
\text { založenia }\end{array}$ & $\begin{array}{l}\text { Počet } \\
\text { ročníkov }\end{array}$ & $\begin{array}{l}\text { Roky konania (ak bol maratón } \\
\text { prerušený) }\end{array}$ \\
\hline 1. & Boston & USA & 04 & 1897 & 122 & $1897-1917,1919-2019$ \\
2. & Yonkers & USA & $09+$ & 1907 & 93 & $1907-1911,1913-1917,1935-2000$, \\
3. & Košice & Slovensko & $10+$ & 1924 & 96 & $1924-1937,1939,1941-2019$ \\
4. & Chiswick & Spojené královstvo & $09+$ & 1909 & 82 & $1909,1911-1914,1919-1974,1976-$ \\
5. & Otsu & Japonsko & $03+$ & 1946 & 74 & \\
6. & Belfast & Spojené královstvo & $05+$ & 1946 & 74 & \\
7. & Kochi & Japonsko & $02+$ & 1946 & 73 & $1946-1958,1960-2019$ \\
8. & Johannesburg & JAR & $03+$ & 1946 & 73 & $1946-1997,1999-2019$ \\
9. & Fukuoka & Japonsko & 12 & 1947 & 72 & \\
10. & Durban & JAR & $09+$ & 1927 & 68 & $1927-1939,1946-1956,1958-2001$ \\
11. & Saint John's & Kanada & 09 & 1950 & 68 & $1950-1957,1959-1969,1971-2019$ \\
12. & Chuncheon & Južná Kórea & $10+$ & 1947 & 68 & $1947-1949,1954-1956,1958-2019$ \\
13. & Hitachinaka & Japonsko & 01 & 1953 & 67 & \\
14. & Oita & Japonsko & 02 & 1953 & 67 & \\
15. & Sasolburg & JAR & 02 & 1951 & 67 & $1951-2012,2014-2019$ \\
\hline
\end{tabular}

Zdroj: Association of Road Racing Statisticians (2019); Vysvetlivky: + beh sa konal aj $v$ iných mesiacoch, uvedený mesiac je najfrekventovanejš́ 
Tab. 3. Desat' najstarších maratónov v Európe podl’a roku založenia

\begin{tabular}{|c|c|c|c|c|c|c|c|}
\hline P. & Mesto & Štát & Rok vzniku & P. & Mesto & Štát & Rok vzniku \\
\hline 1. & Košice & Slovensko & 1924 & 6. & Metz & Francúzsko & 1973 \\
\hline 2. & Enschede & Holandsko & 1947 & 7. & Berlín & Nemecko & 1974 \\
\hline 3. & Essen & Nemecko & 1963 & 8. & Amsterdam & Holandsko & 1975 \\
\hline 4. & Atény & Grécko & 1972 & 9. & Paríž & Francúzsko & 1976 \\
\hline 5. & Göteborg & Švédsko & 1972 & 10. & Redruth & Spojené král'ovstvo & 1977 \\
\hline
\end{tabular}

Zdroj: Association of Road Racing Statisticians (2019): International Running Calendar and runners' resources (2019)

Priestorová lokalizácia maratónov do roku 1980 bola viazaná prioritne na región vtedajšieho západného bloku s výnimkou maratónu v Košiciach, Varšave a Istanbule (obr. 3). Od roku 1978 nastáva expanzia počtu maratónov v metropolách aj v menších mestách Európy. Významným bol rok 1981, kedy odštartovalo 10 nových maratónov a potom sa v každom roku pridávali d’alšie (tab. 4). V roku 1982 pribudol maratón v Eindhovene (ako každoročné podujatie až od roku 1992) a v roku 1996 maratón v L'ubl'ane.

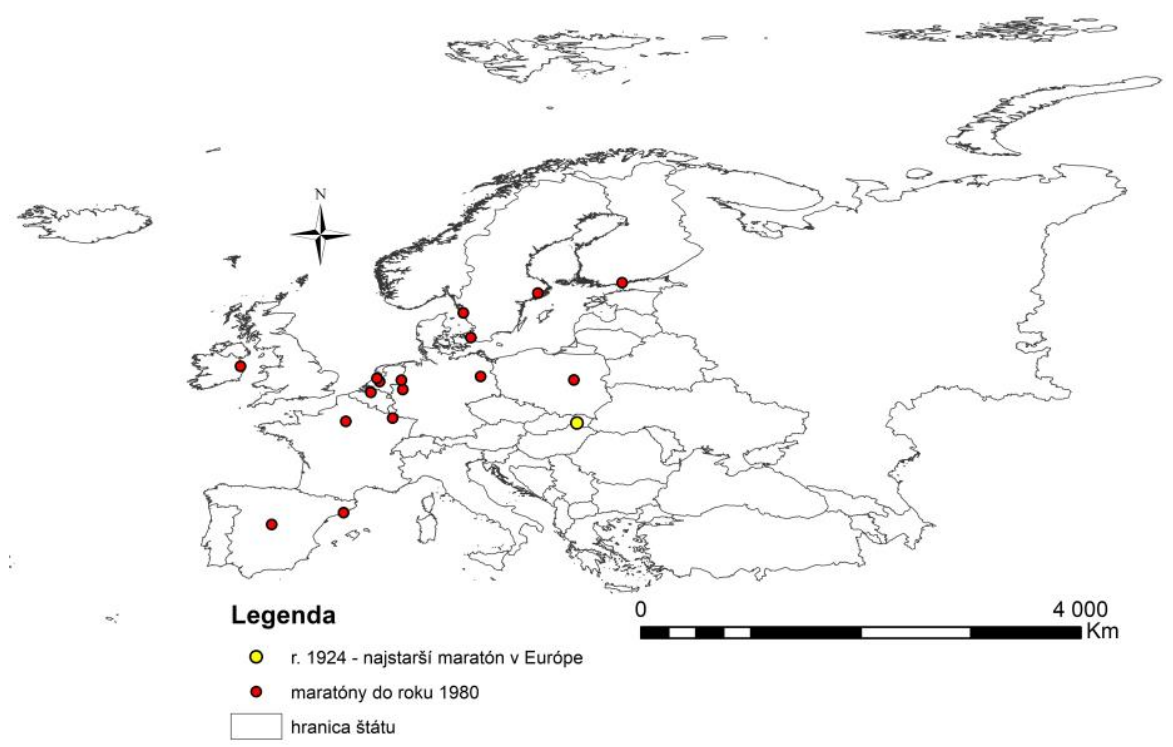

Obr. 3. Maratóny v Európe do roku 1980; Zdroj: World Athletics (2018), vlastné spracovanie

V rokoch 2016, 2018 a 2019 v Európe nevznikli d’alšie maratóny, bolo to prvýkrát od roku 1972. Ďalšie maratóny sa zakladajú skôr v lokalitách mimo Európy. Signalizuje to, že v Európe po 40 rokoch rastu počtu maratónov dochádza $\mathrm{k}$ stagnácii a tiež $\mathrm{k}$ priestorovej redistribúcii bežcov. Do roku 2019 vzrástol počet maratónov oproti roku 1980 viac ako 5-násobne. Sú koncentrované hlavne v západnej Európe, avšak oproti roku 1980 pribudlo niekol'ko desiatok lokalít vo východnej Európe (obr. 4). Ked’že popularita maratónov od roku 2000 výrazne vzrástla, objavujú sa aj v periférnych až extrémnych regiónoch (sever Nórska, Grónsko, Faerské ostrovy) a tiež v malých mestách aj vidieckych obciach.

Medzinárodný maratón v Košiciach získal v roku 2018 hodnotenie IAAF Silver label (v roku 2016 Bronze label), okrem toho v roku 2015 aj certifikát 5 Star Quality Road Race (udelený European Athletics), čo znamenalo významný posun v rankingu a šancu pritiahnut' väčší počet elitných bežcov, aj ked' v čase jeho konania sa koná viacero významných maratónov (Brusel, Kyjev, Casablanca, Trento, Colombo). 
Tab. 4. Maratóny založené a nepretržite pokračujúce v Európe v rokoch 1978 - 2019

\begin{tabular}{|c|c|c|c|}
\hline \multirow{3}{*}{$\begin{array}{l}\text { Rok } \\
1978\end{array}$} & Mesto, obec & Rok & Mesto, obec \\
\hline & Barcelona, Wernigerode (Nemecko), Madrid, & 1999 & Bromöll (Švédsko), Odense \\
\hline & San Sebastian, Utrecht & 2000 & BadArolsen (Nemecko), Dunkerque, Miláno, Poznaň, \\
\hline 1979 & Istanbul, Štokholm, Varšava & & Tallin \\
\hline 1980 & Antwerpy, Kodaň, Dublin, Helsinki & 2001 & Lindau - Bregenz (Nemecko, Rakúsko), Galway, \\
\hline 1981 & $\begin{array}{l}\text { Cardiff, Frankfurt n. M., Londýn, Moskva, Nantes, Notting- } \\
\text { ham, Duisburg, Rotterdam, Radenci (Slovinsko), Valencia }\end{array}$ & 2002 & $\begin{array}{l}\text { Inverness (Vel'ká Británia), Kangerlussuaq (Grónsko) } \\
\text { Krakov. Linz. Münster }\end{array}$ \\
\hline 1982 & $\begin{array}{l}\text { Belfast, Eindhoven, Rim, Lianberis (Vel'ká Británia), } \\
\text { Toruň }\end{array}$ & 2003 & $\begin{array}{l}\text { Düsseldorf, Edinburgh, L’Escala Španielsko), } \\
\text { Zoutelande (Holandsko),Lódż, Vilňus, Zürich }\end{array}$ \\
\hline 1983 & Mníchov, Wroclaw & 2004 & Porto, Postupim, Torshavn (Faerské ostrovy) \\
\hline 1984 & $\begin{array}{l}\text { Brusel, Budapešt', Florencia, Reims, Reykjavík, Viedeň, } \\
\text { Vaxjo (Švédsko) }\end{array}$ & $\begin{array}{l}2005 \\
2006\end{array}$ & $\begin{array}{l}\text { Ženeva, Albert (Francúzsko), Schlieren (Švajčiarsko), } \\
\text { Solún, Lens, Limassol, Luxemburg, Bratislava }\end{array}$ \\
\hline 1985 & Sevilla & 2007 & Cork, Toulouse, Newry (Vel'ká Británia), Medžugorje \\
\hline 1986 & Hamburg, Lisabon & & (Bosna a Hercegovina), Luzern \\
\hline 1987 & Bila Tserkva, Turín & 2008 & Bukurešt', Nice \\
\hline 1988 & Belehrad, Maranello - Carpi (Taliansko) & 2009 & Dingle (Island), Lucca, Marseille, Katowice, Skopje \\
\hline 1989 & Oulu, Tromsø & 2010 & Brighton, Bastad (Švédsko), Chester, Galway, Las \\
\hline 1990 & Omsk & & Palmas, Kielder (Vel'ká Británia) Kyjev, Nikózia \\
\hline 1991 & Hannover, La Rochelle, Leiden, Valetta (Malta), Riga, & 2011 & Kluž \\
\hline & St. Petersburg & 2012 & Milton Keynes, Tartu \\
\hline 1992 & Turku, Záhreb & 2013 & Bournemouth, Lublin, Mosk \\
\hline 1993 & Interkalen (Švajčiarsko), Lausanne & 2014 & Giovinazzo (Taliansko), Helsingborg, Charkov, Rimini \\
\hline 1994 & Oslo, Podgorica & 2015 & Bristol, Kišiňov \\
\hline 1995 & Praha, Gdaňsk & 2016 & - \\
\hline 1996 & L'ublana & 2017 & Birmingham, Gent, Bruggy, Southampton \\
\hline 1997 & Kolín n. R., Monako (Monako) & 2018 & - \\
\hline 1998 & Tampere, Kremsam D. (Rakúsko), Wolverhampton & 2019 & - \\
\hline
\end{tabular}

Zdroj: World Athletics (2019); Vysvetlivky: Viaceré mestá organizujú dva maratóny-napr. Barcelona, Varšava, Galway; kurzívou sú uvedené malé mestá (do 50 tis. obyv.) a 7 vidieckych obcí (Lianberis, Bromöll, Kangerlussuaq, L'Escala, Albert, Schlieren, Bastad), a štát resp. územie štátu (Grónsko, Faerské ostrovy), Maranello - Carpi, Lindau-Bregenz-trasa $z$ mesta do iného mesta

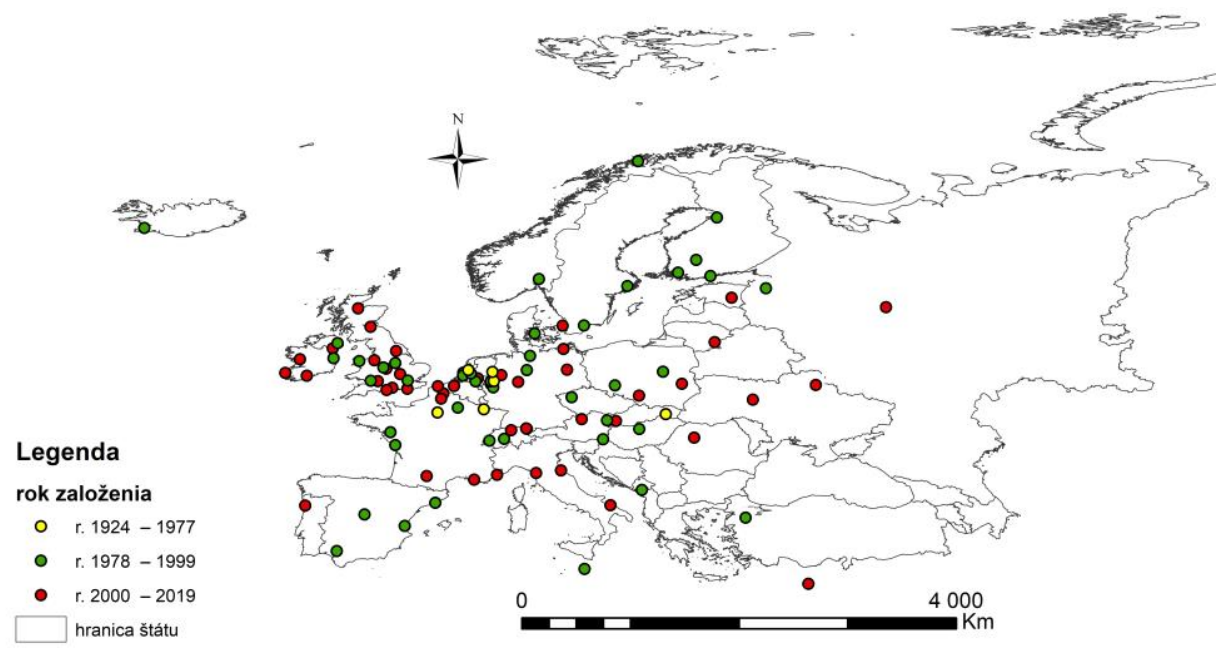

Obr. 4. Etapy vývoja maratónov v Európe v rokoch 1924 - 2019; Zdroj: Association of Road Racing Statisticians (2019), vlastné spracovanie 


\section{Kritérium vývoja tratí}

V drvivej väčšine maratónov prevládajú mestské okruhy tratí. Trend mestských okruhov sa zavádzal postupne od 80 . rokov 20. storočia. Staršie maratóny však prešli rôznymi vývojovými etapami vymedzenia tratí. Trasa najstaršieho maratónu v Bostone je špecifická v porovnaní $\mathrm{s}$ inými okruhmi, pretože si zachováva historické hl'adisko. Trasa začína $\mathrm{v}$ oblasti Nové Anglicko v meste Hopkinton, vedie cez Ashland, Framingham, Natick, Wellesey a končí v Bostone. Na celej svojej dížke klesne o $135 \mathrm{~m}$, teda 3,3 m na každom kilometri (Jones a James 2012). Maratón v Berlíne má povest' trasy, na ktorej bolo dosiahnutých najviac svetových rekordov. Stabilné jesenné počasie, plochá a rovná trat' patria medzi faktory, ktoré podčiarkujú významnost' tohto bežeckého podujatia. Prvý ročník maratónu v Berlíne sa konal v roku 1974 v lese v Grünewalde. V roku 1981 sa presunul do ulíc Západného Berlína a po páde Berlínskeho múru v roku 1990 sa beží celým Berlínom a finišuje pri Brandenburskej bráne. Trat' mestského okruhu je vymedzená ulicami pri Ríšskom sneme, Postupimskom námestí či katedrále. Trat' je plochá, začína v nadmorskej výške $38 \mathrm{~m} \mathrm{n}$. m. a nestúpa vyššie ako na úroveň $53 \mathrm{~m} \mathrm{n}$. m. a nižšie ako $37 \mathrm{~m} \mathrm{n}$. m. (Tužinčin 2013). Pražský maratón len ako mestský okruh sa beží po nábreží Vltavy, pretína niekol'ko mostov, snahou organizátorov je, aby trat' kopírovala významné ulice a námestia v Starom meste. Trat' maratónu v Eindhovene vedie okrem centrálnej časti mesta aj rôznymi parkami, oddychovými zónami, kde je minimálne výškové prevýšenie. Trat' maratónu v Lubl'ane vedie centrálnou čast'ou mesta, odkial' zo stredu pomyselného kruhu prechádza polomerom k periférnym častiam a ciel'ová rovinka je na tom istom mieste ako štart. V prípade maratónu $\mathrm{v}$ Košiciach sa $\mathrm{v}$ doterajšej histórii vystriedalo devät' základných podôb trate. V roku 1924 viedla trat' z Turne do Košíc. V roku 1925 viedla trat' z Košíc do Šebastoviec, Hanisky a spät'. V roku 1926 sa trat' ustálila na trase Košice Seňa a spät'. V roku 1951 sa maratón bežal z Košíc do Lemešian a spät' a v roku 1952 z Prešova do Košíc. V roku 1953 sa maratón vrátil naspät' na trat' Košice - Seňa a spät'. Snaha o zatraktívnenie trate viedla v roku 1989 k prvému prechodu na mestský okruh. Odvtedy prebiehali už iba optimalizácie trate. Posledná výrazná zmena nastala v roku 2009 vynechaním úseku na Námestí osloboditel’ov. Bežia sa dva dížkovo zhodné okruhy (obr. 5).

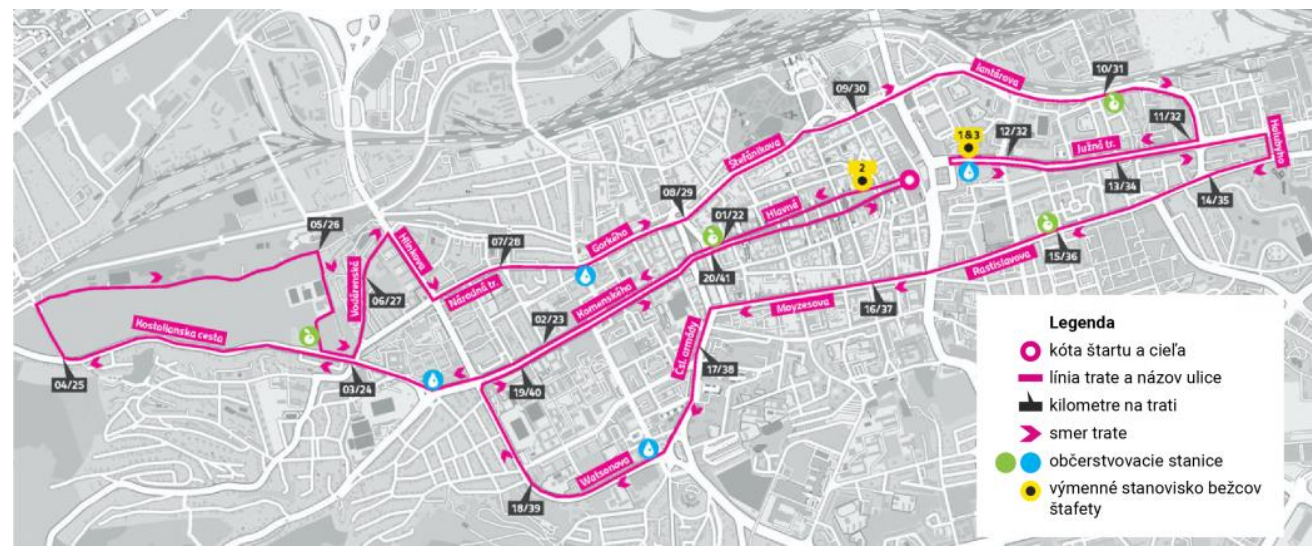

Obr. 5. Schéma trate maratónu v Košiciach; Zdroj: Maratónsky klub Košice (2017), upravené autormi

Mestské okruhy prit’ahujú viac divákov, sprievodné podujatia, a tým aj vyššiu ekonomickú bonitu. Organizátori na webových stránkach maratónov umiestňujú všetky podstatné informácie, vrátane priebehu tratí. V mesiaci október sa konajú aj konkurenčné maratóny v Eindhovene a v L’ubl'ane. V podobnom časovom období ako maratón v Košiciach sa koná aj maratón v Budapešti, ktorého sa zúčastnilo v roku 2019 aj 84 bežcov zo SR (čo je 4,7 \% zahraničných bežcov). 
IAAF udel'uje známky kvality za dosiahnuté športové výsledky a komplexnú organizáciu pretekov od roku 2008. V tabul'ke podl'a kategórií sa umiestnili viaceré nami sledované maratóny (Viedeň, Praha, Lubl'ana, Košice, Varšava, Hannover, Krakov, Porto) (tab. 5).

Tab. 5. Maratóny v Európe v kategóriách Platina, Gold, Silver a Bronze label v roku 2019

\begin{tabular}{l|l|l|l}
\hline Platina label & Gold label & Silver label & Bronze label \\
\hline Berlín, Londýn & Sevilla, Paríž, Rotterdam, Madrid, & Miláno, Rím, Hannover, Var- & Barcelona, Bukurešt', Kra- \\
& Praha, L'ublana, Amsterdam, & šava, Košice, Lisabon & kov, Ženeva, Kodaň, \\
& Frankfurt nad Mohanom, Valen- & & Poznaň, Malaga, Benátky, \\
& cia, Istanbul, Riga, Viedeň & & Porto, Florencia \\
\hline
\end{tabular}

Zdroj: Association of International Marathons and Distance Races (2019)

\section{Kritérium dosiahnutých časov}

Dosiahnuté časy a štatistické ukazovatele z nich vyplývajúce, sú jedným z aspektov komparácie maratónov. V prípade maratónu $\mathrm{v}$ Košiciach je priemer najlepších 10 časov (do roku 2019) 2:07:54, čo je porovnatel'ná hodnota s maratónom v L’ubl’ane (2:07:55). Z porovnávaných maratónov je na tom lepšie o približne pol minúty Viedeň (2:07:19) a o viac ako minútu Eindhoven (2:06:40) i Praha (2:06:31); výrazne horší priemer o takmer 3 minúty má Porto (znevýhodnený absenciou najlepších bežcov kvôli účasti na maratóne v New Yorku). Najmenší rozdiel medzi 10. a 1. najlepším časom má maratón v Eindhovene, nasledovaný maratónom v Košiciach a Prahe (tab. 6).

Tab. 6. Desat' najlepších časov na vybraných maratónoch do roku 2019

\begin{tabular}{l|rrrrrc}
\hline Poradie & Košice & Eindhoven & L'ubl'ana & Praha & Viedeň & Porto \\
\hline 1. & $2: 07: 01$ & $2: 06: 13$ & $2: 04: 58$ & $2: 05: 39$ & $2: 05: 41$ & $2: 09: 05$ \\
2. & $2: 07: 07$ & $2: 05: 46$ & $2: 07: 29$ & $2: 05: 58$ & $2: 06: 36$ & $2: 09: 08$ \\
3. & $2: 07: 49$ & $2: 06: 26$ & $2: 07: 52$ & $2: 06: 07$ & $2: 06: 56$ & $2: 09: 48$ \\
4. & $2: 07: 49$ & $2: 06: 27$ & $2: 08: 06$ & $2: 06: 18$ & $2: 06: 58$ & $2: 09: 51$ \\
5. & $2: 07: 51$ & $2: 06: 39$ & $2: 08: 09$ & $2: 06: 23$ & $2: 07: 24$ & $2: 09: 52$ \\
6. & $2: 08: 08$ & $2: 06: 43$ & $2: 08: 19$ & $2: 06: 25$ & $2: 07: 31$ & $2: 09: 54$ \\
7. & $2: 08: 11$ & $2: 06: 46$ & $2: 08: 25$ & $2: 06: 46$ & $2: 07: 38$ & $2: 10: 41$ \\
8. & $2: 08: 12$ & $2: 06: 58$ & $2: 08: 33$ & $2: 07: 03$ & $2: 07: 44$ & $2: 11: 08$ \\
9. & $2: 08: 15$ & $2: 07: 10$ & $2: 08: 36$ & $2: 07: 11$ & $2: 08: 19$ & $2: 11: 34$ \\
10. & $2: 08: 33$ & $2: 07: 32$ & $2: 08: 41$ & $2: 07: 17$ & $2: 08: 20$ & $2: 11: 48$ \\
\hline Súčet & $21: 18: 56$ & $21: 06: 40$ & $21: 19: 08$ & $21: 05: 07$ & $21: 13: 07$ & $21: 42: 49$ \\
\hline Priemer & $2: 07: 54$ & $2: 06: 40$ & $2: 07: 55$ & $2: 06: 31$ & $2: 07: 19$ & $2: 10: 17$ \\
\hline Rozdiel medzi 10. a 1. poradím & $0: 01: 32$ & $0: 01: 19$ & $0: 03: 43$ & $0: 01: 38$ & $0: 02: 39$ & $0: 02: 43$ \\
\hline
\end{tabular}

Zdroj: Maratónsky klub Košice (2019), Association of Road Racing Statisticians (2019), vlastné výpočty

Vývoj časových rozdielov na MMM dokumentuje klesajúcu kvalitu bežcov. Oproti roku 2012, ked' bol zaznamenaný súčet 10 najlepších časov 21:47:52, došlo do roku 2019 k poklesu takmer o 80 sekúnd (na úroveň roku 2005) a v porovnaní s 10 najlepšími časmi na všetkých maratónoch v Európe v roku 2019 Košice zaostávali o 2,5 minúty. V roku 2019 bol časový rozdiel medzi 10. a 1. časom až 26 minút a medián časov 2:13:17 (tab. 7).

Z porovnávanej trojice vyšiel najlepšie maratón v Eindhovene, kde súčet 10 najlepších časov v roku 2019 síce poklesol oproti roku 2018 o približne 80 sekúnd na hodnotu 21:41:42 (o 90 sekúnd lepší čas ako v Košiciach v roku 2019), na druhej strane rozdiel medzi 10. a 1. časom bol len 9 minút (2019), čo je najlepšia hodnota spomedzi porovnávaných maratónov. Maratón v Lubl'ane dosahuje lepšie časy v porovnaní s Košicami. Priemer 10 najlepších časov bol v roku 2019 lepší oproti Košiciam o 4 minúty, rovnako rozdiel medzi 10. a 1. bežcom v poradí vykazoval lepší výsledok o takmer 3 minúty v porovnaní s Košicami. Aj na základe týchto faktov sa maratóny v L’ubl'ane i Eindhovene pohybujú v rebríčku IAAF vyššie a konkurujú maratónu v Košiciach. 
Tab. 7. Dosiahnuté časy na MMM v Košiciach v rokoch 1985 - 2019

\begin{tabular}{l|cccc}
\hline Rok & $\begin{array}{c}\text { Súčet } \\
\text { 10 najlepších } \\
\text { časov }\end{array}$ & $\begin{array}{c}\text { Priemer } \\
\text { 10 najlepš́ch } \\
\text { časov }\end{array}$ & $\begin{array}{c}\text { Rozdiel medzi } \\
\text { 10. a 1. bežcom } \\
\text { v poradí }\end{array}$ & $\begin{array}{c}\text { Medián } \\
\text { 10 najlepších } \\
\text { časov }\end{array}$ \\
\hline 2019 & $23: 06: 06$ & $2: 18: 37$ & $0: 26: 13$ & $2: 13: 17$ \\
2018 & $22: 23: 35$ & $2: 14: 22$ & $0: 19: 06$ & $2: 12: 30$ \\
2017 & $22: 00: 18$ & $2: 12: 02$ & $0: 13: 39$ & $2: 10: 21$ \\
2016 & $22: 37: 05$ & $2: 15: 42$ & $0: 20: 05$ & $2: 12: 21$ \\
2015 & $22: 46: 46$ & $2: 16: 41$ & $0: 26: 23$ & $2: 12: 33$ \\
2013 & $22: 02: 26$ & $2: 12: 15$ & $0: 10: 29$ & $2: 11: 17$ \\
2010 & $23: 33: 55$ & $2: 21: 23$ & $0: 26: 27$ & $2: 21: 03$ \\
2005 & $23: 06: 16$ & $2: 18: 38$ & $0: 05: 34$ & $2: 17: 48$ \\
2000 & $23: 34: 56$ & $2: 21: 30$ & $0: 14: 05$ & $2: 22: 41$ \\
1995 & $22: 52: 25$ & $2: 17: 14$ & $0: 05: 38$ & $2: 16: 55$ \\
1990 & $24: 13: 39$ & $2: 25: 22$ & $0: 09: 16$ & $2: 25: 30$ \\
1985 & $23: 25: 35$ & $2: 20: 33$ & $0: 06: 43$ & $2: 20: 10$ \\
\hline Súčet 10 najlepších časov na & $20: 36: 15$ & $2: 03: 37$ & $0: 03: 35$ & $2: 03: 36$ \\
maratónoch v Európe v r. 2019 & $20: 35$ \\
\hline
\end{tabular}

Zdroj: Maratónsky klub Košice (2019), vlastné výpočty

\section{Kritérium počtu účastníkov}

Celkový počet účastníkov patrí k hlavným kritériám pri hodnotení maratónov. Vzhl'adom na extrémny záujem o účast' na najlepších svetových maratónoch v poslednom období, museli tieto prikročit' k stanoveniu limitov počtu prihlásených bežcov, kedy je potrebná bud' včasná registrácia, kvalifikácia, prípadne istá forma lotérie. Počet bežcov v cieli je na úrovni priemerne viac ako $75 \%$ všetkých bežcov. V rámci Európy sú maratóny situované v celom spektre významných metropol (Londýn, Paríž, Berlín, Rím), v d’alších hlavných mestách a metropolách, ale aj v stredných a malých mestách a aj obciach do 5000 obyvatel'ov. Svedčí to o výraznej variabilite z hl'adiska vel'kostnej štruktúry miest, čo vplýva aj na rôznorodost' celkovej organizácie maratónov a dopadom na dynamiku mesta. $Z$ hl’adiska zastúpenia hlavných miest je v databáze IAAF podl'a rankingu (2019) zapísaných 24 maratónov v hlavných mestách Európy, čo tvorí len $53 \%$ z tejto kategórie miest (obr. 6).

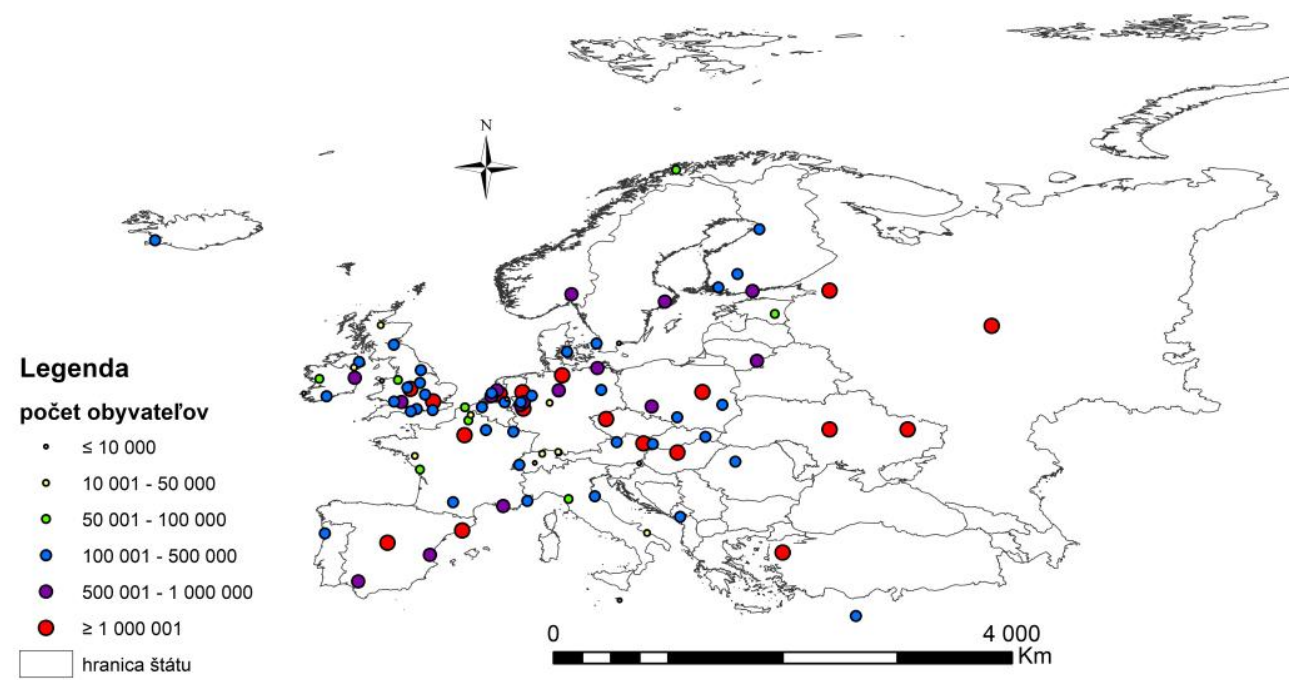

Obr. 6. Maratóny v mestách Európy podl'a počtu obyvatel'ov v roku 2019; Zdroj: City Population (2019), Association of Road Racing Statisticians (2019), vlastné spracovanie 
V rámci komparácie uvádzame príklady 13 vybraných maratónov v Európe vrátane maratónov v krajinách V4. Metropoly susedných štátov patria do vyšších vel'kostných kategórií miest oproti Košiciam, rovnako aj počet bežcov je vyšší, ale v celkovom hodnotení niektoré z nich zaostávajú za Košicami (Budapešt', Varšava, Krakov). Celkovým počtom účastníkov v hlavnej kategórii sú Košice porovnatel'né s mestami Lubl'ana, Padova, Lausanne, Hannover a Graz (ten však v posledných rokoch zaznamenal pokles účasti). V Eindhovene bežalo v roku 2019 o $51 \%$ viac bežcov ako v Košiciach. Maratóny v Prahe, Budapešti, Varšave a vo Viedni síce vykazujú účast' bežcov aj viac ako 3-krát vyššiu (tab. 8), relatívne (na počet obyvatel'ov) však za Košicami zaostávajú (tab.9). Najvýraznejší nárast počtu bežcov za sledované obdobie 1995 - 2019 dosiahol maratón v Prahe (v rokoch 1995 - 2009 až 7-krát, od roku 2010 rast len o 50 \%). Výrazný rast účasti od založenia v roku 2002 zaznamenal aj Krakov. Najväčší rozptyl (hodnotu variačného koeficientu) v sledovaných rokoch vykazujú maratóny vo Varšave a v Krakove (viac ako 6750 bežcov). V poslednom období už nedochádza k výraznému nárastu počtu bežcov. Väčšina porovnávaných maratónov za posledné roky stagnuje, resp. zaznamenáva pokles účasti (Košice, Budapešt', Varšava, Viedeň, Krakov, Lausanne, Terst, Graz) (tab. 8).

Tab. 8. Počet bežcov na vybraných európskych maratónoch v rokoch $1995-2019$

\begin{tabular}{|c|c|c|c|c|c|c|c|c|c|c|c|c|c|}
\hline $\begin{array}{l}\text { rok/ } \\
\text { lokalita }\end{array}$ & $\begin{array}{l}\bar{\sigma} \\
\frac{0}{0 .} \\
\bar{\delta}\end{array}$ & 尊 & 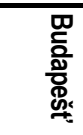 & 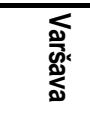 & 产 & 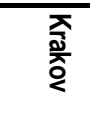 & $\frac{\text { Q }}{\stackrel{N}{\mathcal{N}}}$ & 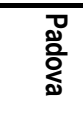 & 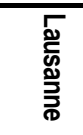 & 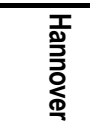 & $\frac{\overrightarrow{0}}{\frac{0}{2}}$ & 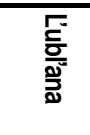 & 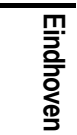 \\
\hline 2019 & 1604 & 7301 & 4532 & 4692 & 5693 & 5630 & 549 & 1244 & 1207 & 2222 & & 1556 & 2423 \\
\hline 2018 & 1617 & 6950 & 5351 & 7529 & 6341 & 7477 & 650 & 1355 & 1356 & 2017 & 432 & 1432 & 2083 \\
\hline 2017 & 1547 & 6510 & 5415 & 5459 & 6320 & 5614 & 678 & 1541 & 1261 & 1967 & 399 & 1488 & 2140 \\
\hline 2016 & 1614 & 5777 & 4969 & 5921 & 6481 & 5548 & 619 & 1740 & 1317 & 1857 & 622 & 1688 & 2149 \\
\hline 2015 & 1379 & 5871 & 5604 & 6491 & 5949 & 4581 & 714 & 1374 & 1273 & 1809 & 666 & 1813 & 2022 \\
\hline 2014 & 1396 & 5846 & 4348 & 6679 & 6347 & 5378 & 884 & 1432 & 1164 & 1728 & 665 & 1832 & 1315 \\
\hline 2013 & 1545 & 5766 & 3991 & 8506 & 6878 & 4414 & 1011 & 1733 & 1401 & 1532 & 643 & 1632 & 1416 \\
\hline 2012 & 864 & 5649 & 3585 & 6796 & 5888 & 3014 & 846 & 494 & 1223 & 1524 & 695 & 1232 & 1277 \\
\hline 2011 & 823 & 5296 & 2984 & 4061 & 5942 & 3205 & 622 & 569 & 1287 & 1544 & 681 & 1204 & 1278 \\
\hline 2000 & 499 & 2776 & 2444 & 587 & 8493 & $n$ & 2029 & 406 & 1722 & 284 & 824 & 289 & 383 \\
\hline 1995 & 549 & 519 & $\mathrm{n}$ & 779 & 4952 & $\mathrm{n}$ & $\mathrm{n}$ & $n$ & 171 & 207 & $n$ & $\mathrm{n}$ & $\mathrm{n}$ \\
\hline Súčet & 21240 & 99626 & 71599 & 78083 & 157252 & 55740 & 23877 & 15280 & 32086 & 30449 & 10652 & 21665 & 24342 \\
\hline Priemer & 849,6 & 3985 & 2983 & 3123 & 6290 & 3096 & 1038 & 764 & 1283 & 1217 & 532 & 902 & 1014 \\
\hline VK & 444,9 & 1832,3 & 1385,8 & 2575,3 & 1151,7 & 2131,8 & 372,3 & 546,5 & 462,10 & 655,93 & 142,6 & 567,4 & 671,7 \\
\hline VR & 1055 & 6782 & 3794 & 3913 & 741 & 4912 & -657 & 838 & 1036 & 2015 & -824 & 1403 & 1994 \\
\hline $\begin{array}{l}\% R / P \text { do } \\
\text { roku } 2009 \\
\end{array}$ & 51,6 & 666,1 & 223,6 & 306,2 & 1,03 & 150,3 & $-30,6$ & $-39,7$ & 645,0 & 594,2 & $-33,5$ & 240,8 & 73,6 \\
\hline $\begin{array}{l}\text { \%R/P v rokoch } \\
2010-2019\end{array}$ & 109,1 & 43,0 & 101,3 & 126,6 & 25,5 & 209,3 & $-30,4$ & 249,0 & 1,0 & 25,9 & $-29,6$ & 23,8 & 99,5 \\
\hline $\begin{array}{l}\text { \%R/P do } \\
\text { roku } 2019\end{array}$ & 192,2 & 306,7 & 514,1 & 502,3 & 14,9 & 684,1 & $-54,5$ & 206,4 & 605,8 & 973,4 & $-100,0$ & 438,4 & 532,6 \\
\hline
\end{tabular}

Zdroj: Association of Road Racing Statisticians (2019), vlastné výpočty;

Vysvetlivky: VK - variačný koeficient, VR - variačné rozpätie, $\% R / P$ - percentuálny rast/pokles, $n$-nezískané údaje, chýbajúce roky kvôli rozsahu skryté

Od svojho vzniku zaznamenal maratón v Košiciach dve významné lokálne maximá počtu bežcov, a to v 80. rokoch 20. storočia a od roku 2013. Rapídny nárast nastal v roku 1980 (1 095 bežcov mužov, v roku 1979 len 77). Od roku 2013 je počet štartujúcich stále vyšší ako 1300 . Pri zvážení vel'kostnej kategórie usporiadatel'ských miest je vhodnejšie použit' relatívny počet účastníkov na 1000 obyvatel'ov (tab. 9). Z porovnávaných maratónov jednoznačne najvyššiu hodnotu dosiahol v roku 2019 Eindhoven (10,5), nasledujú Lausanne, Krakov, Košice $(6,7)$ a Praha $(5,6)$, najnižšie hodnoty mali Viedeň $(3,0)$, Varšava a Budapešt' (obidve 2,6$)$. 
Tab. 9. Počet bežcov na 1000 obyv. na vybraných maratónoch v rokoch 1995 - 2019

\begin{tabular}{|c|c|c|c|c|c|c|c|c|c|c|c|c|c|}
\hline Rok/Mesto & 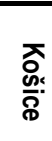 & 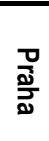 & 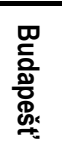 & 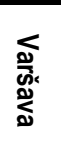 & $\begin{array}{l}\text { ब. } \\
\frac{0}{9} \\
\frac{0}{3}\end{array}$ & 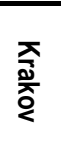 & 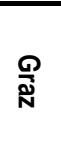 & $\begin{array}{l}\text { ఖँ } \\
\text { 이 }\end{array}$ & 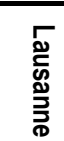 & 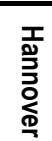 & $\stackrel{\overrightarrow{9}}{\frac{9}{9}}$ & 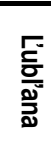 & 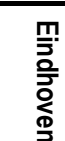 \\
\hline 2019 & 6,7 & 5,6 & 2,6 & 2,6 & 3,0 & 7,4 & 1,7 & 5,9 & 8,8 & 4,3 & $\mathrm{n}$ & 5,3 & 10,5 \\
\hline 2018 & 6,8 & 5,4 & 3,0 & 4,3 & 3,4 & 9,7 & 1,5 & 6,5 & 9,8 & 3,8 & 2,1 & 4,9 & 9,1 \\
\hline 2017 & 6,5 & 5,1 & 3,1 & 2,9 & 3,4 & 7,3 & 1,6 & 7,3 & 9,2 & 3,7 & 2,0 & 5,3 & 9,4 \\
\hline 2016 & 6,7 & 4,6 & 2,8 & 3,2 & 3,5 & 7,2 & 1,4 & 8,3 & 9,7 & 3,5 & 2,6 & 6,0 & 9,6 \\
\hline 2015 & 5,8 & 4,7 & 3,2 & 3,6 & 3,3 & 6,0 & 1,7 & 6,5 & 9,5 & 3,5 & 2,8 & 6,5 & 9,1 \\
\hline 2010 & 3,3 & 3,9 & 1,5 & 2,0 & 3,0 & 3,2 & 2,4 & 1,8 & 10,5 & 3,1 & 2,6 & 4,2 & 4,9 \\
\hline 2005 & 2,2 & 2,9 & 1,6 & 1,0 & 3,2 & 1,2 & 3,3 & 1,6 & 15,3 & 2,6 & 1,5 & 2,6 & 2,7 \\
\hline 2000 & 2,1 & 2,4 & 1,5 & 0,4 & 5,5 & $\mathrm{n}$ & 5,8 & 2,0 & 13,8 & 0,6 & 3,4 & 1,1 & 1,9 \\
\hline 1995 & 2,3 & 0,4 & $\mathrm{n}$ & 0,5 & 3,2 & $\mathrm{n}$ & $\mathrm{n}$ & $\mathrm{n}$ & 1,4 & 0,4 & $\mathrm{n}$ & $\mathrm{n}$ & $\mathrm{n}$ \\
\hline
\end{tabular}

Zdroj: vlastné výpočty; Vysvetlivky: $n$-nezistené údaje

\section{Kritérium zastúpenia zahraničných vít'azov}

Ranking maratónu dopíňa aj kritérium zastúpenia zahraničných vít’azov a tiež počet bežcov, ktorí dosiahli čas lepší ako stanovený limit pre konkrétny rok. Domáci bežci sa v sledovanom období (1995 - 2019) stali vít'azmi len v prípade Budapešti. Ovel’a častejšie obsadzovali poradie od 20. miesta, resp. sa umiestnili v strednej a spodnej časti rebríčka. Neeurópski vít’azi v sledovanom období mali najvyššie zastúpenie na maratónoch v Eindhovene a Prahe. Podiel domácich bežcov bol na maratóne v Košiciach na úrovni 78,7 \% (pre porovnanie na maratóne v Bratislave ich v roku 2019 bolo 55,7 \%), v Lubl'ane $52 \%$ a v Eindhovene $44 \%$. Viac ako $62 \%$ domácich bežcov bolo na maratóne v Budapešti, Krakove a Varšave. Vo všetkých porovnávaných maratónoch s výnimkou Budapešti a Varšavy dominujú od roku 1995, resp. 1996 bežci z Kene, nasledovaní bežcami z Etiópie. V prípade Košíc títo bežci zvít'azili na všetkých pretekoch od roku 2005. Skupina 15 - 20 Afričanov zvyčajne obsadzuje väčšinu miest v prvej desiatke bežcov. Finančné odmeny na maratóne v Košiciach získava prvých 10 mužov a 6 žien v konečnom poradí, pričom títo africkí bežci nepatria do najlepšej svetovej špičky. Z hl'adiska finančnej motivácie maratón v Košiciach nemôže konkurovat' najlepším svetovým maratónom. Maratón v Budapešti vykazuje najvyššie percento účasti domácich bežcov a tiež vysoký podiel domácich vít’azov (od roku 1996 do 2018 až 16 domácich vít’azov, čo je takmer $70 \%$ ), ked' vít'azov z Afriky bolo len 6. Vysoký počet domácich vít'azov (11) vykazoval tiež maratón vo Varšave, ale od roku 2006 to boli len dvaja. Ostatné maratóny majú zastúpenie vít’azov rozmanitejšie. Účast' na maratónoch v krajinách V4 charakterizuje silné zastúpenie domácich bežcov vo vyšších vekových kategóriách s časmi výrazne horšími oproti najlepším svetovým časom.

\section{Kritérium pohlavia účastníkov}

Ženy sa prvýkrát postavili na štart v Košiciach v roku 1980 (ženský maratón na letnej olympiáde v Los Angeles sa bežal prvýkrát až v roku 1984) (Koniar, Matia, Šimo, 2014). Postupne ich počet narastá a dnes podiel žien dosahuje priemerne $30 \%$, na niektorých významných maratónoch atakuje úroveň $50 \%$ (Andersen, 2019). V porovnaní kontinentov dosahuje Európa najnižšie hodnoty - 22 \% (Severná Amerika 44,8 \%, Južná Amerika 26,3 \%, Ázia, 27,9\%). Pre ilustráciu, v roku 2018 dokončilo maratón v Bostone $45 \%$ žien zo všetkých pretekárov, v New Yorku to bolo $42 \%$, v Prahe a v Tokiu viac ako 22\%. Maratón v Berlíne je známy vyššou účast'ou žien (30 \% v roku 2018; a od roku 2005 podiel žien neklesol pod 20 $\%)$, a tým je na úrovni svetového priemeru.

Pri komparácii maratónov v Košiciach, Eindhovene a L’ubl’ane platí, že najvyšší podiel žien bol v Lubl’ane (v roku 2019 už druhýkrát vy̌̌ší ako 20 \%). Túto hodnotu už pravidelne prevyšovali v posledných rokoch maratóny vo Viedni a v Prahe a v rokoch 2008 - 2012 aj Eindhoven, v d'alších rokoch nastal pokles (17,9 \% 2019). Košice majú v tomto ukazovateli 
najslabšie zastúpenie, v roku 2019 dosiahli prvýkrát hodnotu 14 \% a v roku 2010 prvýkrát prevýšili hodnotu $10 \%$ (tab. 10). Nad'alej platí, že väčšinu bežcov vo vybraných maratónoch tvoria muži (viac ako $80 \%$ ).

Tab. 10. Podiel mužov a žien na vybraných maratónoch v rokoch $1996-2019$ v \%

\begin{tabular}{|c|c|c|c|c|c|c|c|c|c|c|}
\hline \multirow{2}{*}{$\begin{array}{c}\text { Mesto } \\
\text { Rok }\end{array}$} & \multicolumn{2}{|c|}{ Košice } & \multicolumn{2}{|c|}{ Eindhoven } & \multicolumn{2}{|c|}{ L'ubl'ana } & \multicolumn{2}{|c|}{ Praha } & \multicolumn{2}{|c|}{ Viedeň } \\
\hline & muži & ženy & muži & ženy & muži & ženy & muži & ženy & muži & ženy \\
\hline 2019 & 86,0 & 14,0 & 82,1 & 17,9 & 78,5 & 21,5 & 77,6 & 22,4 & 77,6 & 22,4 \\
\hline 2018 & 86,1 & 13,9 & 81,7 & 18,3 & 84,9 & 15,1 & 78,2 & 21,8 & 78,3 & 21,7 \\
\hline 2017 & 86,3 & 13,7 & 83,7 & 16,3 & 87,2 & 12,8 & 77,7 & 22,3 & 78,3 & 21,7 \\
\hline 2016 & 86,2 & 13,8 & 89,3 & 10,7 & 78,1 & 21,9 & 78,1 & 21,9 & 79,6 & 20,4 \\
\hline 2015 & 89,2 & 10,8 & 85,4 & 14,6 & 88,2 & 11,8 & 81,6 & 18,4 & 81,2 & 18,8 \\
\hline 2014 & 89,3 & 10,7 & 86,7 & 13,3 & 86,8 & 13,2 & 81,6 & 18,4 & 81,7 & 18,3 \\
\hline 2013 & 89,5 & 10,5 & 85,9 & 14,1 & 82,5 & 17,5 & 83,2 & 16,8 & 81,2 & 18,8 \\
\hline 2010 & 91,6 & 8,4 & 71,6 & 28,4 & 87,0 & 13,0 & 83,4 & 16,6 & 83,7 & 16,3 \\
\hline 2005 & 93,5 & 6,5 & $n$ & $\mathrm{n}$ & 90,3 & 9,7 & 86,2 & 13,8 & 85,5 & 14,5 \\
\hline 2000 & 95,3 & 4,7 & $n$ & $n$ & 87,5 & 12,5 & 87,9 & 12,1 & 88,1 & 11,9 \\
\hline 1996 & 95,6 & 4,4 & $n$ & $n$ & 94,8 & 5,2 & 91,8 & 8,2 & 92,2 & 7,8 \\
\hline
\end{tabular}

\section{Kritérium štruktúry účastníkov podl'a štátov a miery diverzity}

Medzinárodnú atraktivitu dobre dokumentuje štruktúra účastníkov podl’a krajín. Štruktúra účastníkov vyjadruje rôzne vývojové štádia maratónu. Účastníkmi Košického maratónu boli v 80. rokoch 20. storočia dominantne bežci z krajín tábora socializmu (Česko, Pol'sko, Mad'arsko), ktorí tvorili viac ako 50 \% všetkých účastníkov. Od roku 1990 sa zvyšoval podiel slovenských bežcov, čo je aj dôsledkom rozdelenia Československa, rastúceho počtu maratónov v Európe a rastúca (aj ekonomická) atraktivita novších maratónov. Významné zastúpenie si dlhodobo udržiavajú tri susedné krajiny (tab. 11), ale v posledných rokoch podiel bežcov z týchto krajín je nižší ako $15 \%$. Podiel bežcov z ostatných štátov po významnom raste začiatkom 90. rokov poklesol a udržuje sa v intervale 6 až $9 \%$. Miera diverzity na MMM v sledovanom období mala klesajúci trend (v roku 1980 mala hodnotu 0,57, v roku 2019 hodnotu 0,37), čo len dokazuje stagnáciu resp. pokles zahraničnej účasti (tab. 11). Výnimkami boli roky, kedy boli Košice nominované na európske mesto. V roku 2016 boli Košice Európskym mestom športu (takmer 19 \% účastníkov z Česka, Pol'ska a Mad'arska) a v roku 2013 boli Európskym hlavným mestom kultúry (takmer $26 \%$ účastníkov z troch susedných krajín).

Tab. 11. Vývoj štruktúry účastníkov na MMM v Košiciach v rokoch 1980 - 2019

\begin{tabular}{c|cccc}
\hline Śtát/Rok & \% Slovensko & $\begin{array}{c}\text { \% Cesko, Pol'sko, } \\
\text { Mad'arsko }\end{array}$ & \% ostatné štáty & $\begin{array}{c}\text { Miera } \\
\text { diverzity }\end{array}$ \\
\hline $\mathbf{2 0 1 9}$ & 78,7 & 13,5 & 7,8 & 0,373 \\
$\mathbf{2 0 1 8}$ & 81,1 & 13,1 & 5,8 & 0,327 \\
$\mathbf{2 0 1 7}$ & 77,2 & 16,0 & 6,8 & 0,394 \\
$\mathbf{2 0 1 6}$ & 73,6 & 18,9 & 7,5 & 0,446 \\
$\mathbf{2 0 1 5}$ & 78,3 & 15,9 & 5,8 & 0,377 \\
$\mathbf{2 0 1 4}$ & 72,3 & 21,8 & 5,9 & 0,459 \\
$\mathbf{2 0 1 3}$ & 66,5 & 25,9 & 7,6 & 0,531 \\
$\mathbf{2 0 1 2}$ & 74,3 & 18,1 & 7,6 & 0,435 \\
$\mathbf{2 0 1 0}$ & 70,6 & 20,9 & 8,5 & 0,482 \\
$\mathbf{2 0 0 5}$ & 55,6 & 35,0 & 9,4 & 0,600 \\
$\mathbf{2 0 0 0}$ & 76,4 & 17,7 & 5,9 & 0,396 \\
$\mathbf{1 9 9 5}$ & 71,3 & 17,9 & 11,7 & 0,479 \\
$\mathbf{1 9 9 0}$ & 72,8 & 22,9 & 4,3 & 0,419 \\
$\mathbf{1 9 8 5}$ & 64,4 & 30,0 & 5,6 & 0,500 \\
$\mathbf{1 9 8 0}$ & 48,4 & 50,7 & 0,9 & 0,574 \\
\hline
\end{tabular}

Zdroj: Maratónsky klub Košice (2019), vlastné výpočty 
Pri tomto kritériu sa pri porovnaní Košického maratónu obmedzíme len na L’ubl’anu a Eindhoven. Maratón v Luubl’ane zaznamenal výrazný nárast nielen v počte účastníkov (porovnatel'ný s Košicami aj napriek krátkej dížke trvania), ale aj v zvýšení podielu zahraničných bežcov z 2,8 \% bežcov v roku 1996 (hlavne z Talianska, Chorváti sa v úvodných ročníkoch takmer nevyskytovali aj z vnútropolitických dôvodov) až po vysokých 48,1 \% (2019). Pričom viac ako $18 \%$ tvoria bežci zo štátov bývalej Juhoslávie (najviac Chorváti - $11 \%$, nasledujú Srbi a bežci z Bosny a Hercegoviny). Z ostatných štátov majú najvyššie zastúpenie Taliani, Mad'ari, Briti a Belgičania. Miera diverzity vzrástla z hodnoty 0,27 v roku 1997 až na 0,7 v roku 2019, čo dokazuje rast medzinárodnej atraktivity. Maratón v Eindhovene je špecifický tým, že má vel'mi silné zastúpenie bežcov zo susedného Belgicka (32 - 44\%), ktorí mali dokonca v niektorých rokoch vyššie zastúpenie ako domáci bežci. Medzi ostatné silnejšie zastúpené štáty patria Francúzsko, Vel'ká Británia, Pol’sko, Taliansko a Grécko. Dominantné postavenie bežcov z Kene a Etiópie na maratónoch v Košiciach, Eindhovene či L’ubl'ane stále pretrváva. Pri všetkých troch maratónoch je evidentné aj silné zastúpenie bežcov zo susedných krajín, resp. z politicky a historicky príbuzných bývalých zoskupení.

\section{Kritérium vekovej štruktúry účastníkov}

Maratón v Košiciach je v ostatnom období skôr pretekom bežcov vy̌šśch vekových kategórií. Za posledných 50 rokov vzrástol mediánový vek mužov o 10 rokov na hodnotu 41 rokov (v roku 2019) (rovnako aj modus), v prípade žien ešte o rok viac (medián 42 rokov a modus 38 rokov) (tab. 12).

Tab. 12. Štruktúra účastníkov na MMM podl’a mediánu a modusu veku v rokoch 1980 - 2019

\begin{tabular}{c|cc|cc|cc|cc}
\hline & \multicolumn{3}{|c|}{ Všetci bežci } & \multicolumn{3}{c}{ Bežci zo Slovenskej republiky } \\
\hline Pohlavie & \multicolumn{2}{|c|}{ Muži } & \multicolumn{2}{c|}{ Ženy } & \multicolumn{3}{c}{ Muži } & \multicolumn{2}{c}{ Ženy } \\
\hline Rok & medián veku & modus veku & medián veku & modus veku & medián veku & modus veku & medián veku modus veku \\
\hline $\mathbf{2 0 1 9}$ & 41 & 41 & 42 & 38 & 41 & 41 & 42 & 38 \\
$\mathbf{2 0 1 8}$ & 41 & 48 & 37 & 37 & 40 & 40 & 37 & 37 \\
$\mathbf{2 0 1 7}$ & 40 & 40 & 38 & 45 & 40 & 40 & 39 & 43 \\
$\mathbf{2 0 1 6}$ & 40 & 39 & 38 & 44 & 39 & 39 & 38 & 44 \\
$\mathbf{2 0 1 5}$ & 39 & 41 & $n$ & $n$ & 39 & 41 & $n$ & $n$ \\
$\mathbf{2 0 1 4}$ & 39 & 42 & 38 & 30 & 39 & 40 & 38 & 34 \\
$\mathbf{2 0 1 3}$ & 40 & 42 & 39 & 30 & 39 & 39 & 35,5 & 30 \\
$\mathbf{2 0 1 0}$ & 40 & 33 & 33 & 29 & 39 & 39 & 33 & 29 \\
$\mathbf{2 0 0 5}$ & 41 & 29 & 42 & 44 & 42 & 44 & 44,5 & 28 \\
$\mathbf{2 0 0 0}$ & 43 & 46 & 40 & 52 & 45 & 46 & 41,5 & 52 \\
1995 & 38 & 41 & 36 & 34 & 41 & 41 & 42,5 & 46 \\
1990 & 38 & 39 & 32 & 26 & 40 & 41 & 33 & 38 \\
1985 & 33 & 32 & 28 & 24 & 34 & 36 & 36,5 & 39 \\
1980 & 32 & 31 & 29 & 24 & 34 & 31 & 30 & 24 \\
\hline
\end{tabular}

Zdroj: Maratónsky klub Košice (2019), vlastné výpočty; Vysvetlivky: $n$-nezískané údaje

K výraznejšej zmene došlo v rokoch 1995 - 2000, kedy mediánový vek bežcov vzrástol o 5 rokov, čo spôsobila popularizácia behu, rast možností štartu pre širšie vekové skupiny, zmena sociálneho správania, demografické zmeny. Do roku 1985 väčšinu bežcov na MMM z bývalého Československa tvorili bežci z Česka (v roku 1960 - 69,5 \%, 1970 - 61,2 \%, 1980 $-53,9 \%, 1985-31 \%, 1990-22 \%)$.

Maratón v L'ubl'ane je na tom podobne ako maratón v Košiciach. V roku 2019 bol priemerný vek všetkých bežcov 42 rokov (medián 44 rokov) a najpočetnejší bežci boli tiež vo veku 42 rokov (pre staršie ročníky informácia o veku nie je k dispozícii). Maratón v Eindhovene vykazoval najviac bežcov v kategórii 35 až 45 rokov, priemerný vek bežcov bol 39 rokov (2019), (v roku 2018 to bolo 40 rokov), čo je mierne lepšia situácia v porovnaní s Košicami a L’ubl'anou. 


\section{Kritérium marketingu, finančnej prémie a iných bonusov}

Maratóny sa stávajú aj spoločenským podujatím, ktoré prit’ahuje pozornost' divákov a koncentruje sa do historických centier metropol. Mnohé maratónske trate začínajú alebo končia pri významných monumentoch (napr. v Paríži pri Vít’aznom oblúku; v Ríme je po trase viacero historických dominánt, v Prahe po nábreží Vltavy). Ak je maratón súčast'ou významného športového podujatia, sú prípady, že jeho ciel'ová čast' je situovaná na štadióne, ktorý nemusí byt' $\mathrm{v}$ centre mesta. Počet divákov sa uvádza orientačne (spresnenie počtu by mohlo nastat' využitím dronov, či iných informačných systémov) a nie vždy je dostatočne presný. Maratóny v niektorých metropolách sleduje popri trati viac ako milión divákov. Stránka maratónu v Eindhovene uvádza odhad až do 200000 divákov, L'ubl’ana 40000 až 50 000. Výrazný vplyv na účast' elitných bežcov v poslednom období majú predovšetkým finančné odmeny pre vít'azov (tab. 13).

Tab. 13. Finančné provízie, prémie a sponzori vybraných maratónov v roku 2019

\begin{tabular}{|c|c|c|c|c|c|}
\hline Mesto & $\begin{array}{l}\text { Najvyšší } \\
\text { počet } \\
\text { bežcov }\end{array}$ & $\begin{array}{l}\text { Odhad } \\
\text { počtu } \\
\text { divákov }\end{array}$ & $\begin{array}{c}\text { Odmena pre } \\
\text { vít'aza (prepočet } \\
\text { na eurá) }\end{array}$ & $\begin{array}{c}\text { Bonusy za } \\
\text { rekordy } \\
\text { (prepočet na eurá) }\end{array}$ & $\begin{array}{l}\text { Prémia } \\
\text { za svetový } \\
\text { rekord }\end{array}$ \\
\hline Boston & 35868 & 500000 & $\begin{array}{r}150000 \text { USD } \\
(137600 \text { EUR })\end{array}$ & $\begin{array}{r}150000 \text { USD } \\
(137600 \text { EUR) }\end{array}$ & $\begin{array}{l}50000 \text { USD Adidas, Special Olympics } \\
\text { (45 } 900 \text { EUR) Massachussets }\end{array}$ \\
\hline New York & 51388 & $1000000+$ & $\begin{array}{l}100000 \text { USD } \\
\text { (91 } 940 \text { EUR) }\end{array}$ & $\begin{array}{r}500000 \text { USD } \\
(459000 \text { EUR) } \\
\end{array}$ & $\begin{array}{l}\text { n Tata Consultancy Servi- } \\
\text { ces (TCS) }\end{array}$ \\
\hline Berlín & 44389 & 1000000 & $\begin{array}{r}50000 \text { USD } \\
(45900 \text { EUR) }\end{array}$ & $\begin{array}{r}206830 \text { USD } \\
(190000 \text { EUR) }\end{array}$ & $\begin{array}{l}69000 \text { USD BMW, Adidas, Abbot, Giti } \\
\text { (63 } 300 \text { EUR) }\end{array}$ \\
\hline Chicago & 44610 & 1700000 & $\begin{array}{l}100000 \text { USD } \\
\text { (91 } 750 \text { EUR) }\end{array}$ & $\begin{array}{r}420000 \text { USD } \\
(385300 \text { EUR) }\end{array}$ & $\begin{array}{l}75000 \text { USD Bank of America } \\
\text { (68 } 800 \text { EUR) }\end{array}$ \\
\hline Londýn & 39487 & 750000 & $\begin{array}{r}55000 \text { GBP } \\
(65220 \text { EUR) } \\
\end{array}$ & $\begin{array}{r}850000 \text { GBP } \\
(1008000 \text { EUR) } \\
\end{array}$ & $\begin{array}{l}125000 \text { GBP Virgin Money } \\
\text { (148 250 EUR) }\end{array}$ \\
\hline Tokio & $\mathrm{n}$ & $690000+$ & $\begin{array}{r}80000 \text { USD (73 } \\
400 \text { EUR) }\end{array}$ & $\begin{array}{r}460000 \text { USD } \\
\text { (422 } 000 \text { EUR) }\end{array}$ & $\begin{array}{l}300000 \text { USD Tokio Metro } \\
(275200 \text { EUR) }\end{array}$ \\
\hline Košice & 4557 & 60000 & 20000 EUR & do 16000 EUR & n U.S. Steel \\
\hline Eindhoven & 2500 & $160000+$ & $n$ & $\mathrm{n}$ & $\begin{array}{l}\text { n Gemeente Eindhoven, } \\
\text { ASML }\end{array}$ \\
\hline L'ubl'ana & 24372 & $40000+$ & 90000 EUR & & n Volkswagen \\
\hline Praha & 16500 & $30000+$ & 15000 EUR & 10000 EUR & 100000 EUR Volkswagen \\
\hline Viedeň & 42766 & 1000000 & 15000 EUR & $\mathrm{n}$ & $\begin{array}{c}\text { n Erste Group, Hervis, } \\
\text { Wien Energie }\end{array}$ \\
\hline Budapešt' & 33495 & $n$ & $n$ & $\mathrm{n}$ & n SPAR \\
\hline Varšava & 8492 & $n$ & $\begin{array}{r}25000 \text { PLN } \\
\text { (5 900 EUR) }\end{array}$ & $\mathrm{n}$ & $\begin{array}{l}\text { n Powszechny Zakład } \\
\text { Ubezpieczeń }\end{array}$ \\
\hline Krakow & 5630 & $n$ & $\begin{array}{r}20000 \text { PLN } \\
(4700 \text { EUR) }\end{array}$ & $\begin{array}{r}20000 \text { PLN } \\
(4700 \text { EUR) }\end{array}$ & $\begin{array}{l}\text { n Powszechny Zakład } \\
\text { Ubezpieczeń }\end{array}$ \\
\hline Graz & 6582 & 40000 & $\mathrm{n}$ & $\mathrm{n}$ & n Kleine Zeitung \\
\hline Padova & $n$ & $\mathrm{n}$ & 3000 EUR & $\mathrm{n}$ & n Alí \& Aliper, Nike \\
\hline Lausanne & 10658 & 2500 & $\begin{array}{r}2000 \mathrm{CHF} \\
(1880 \mathrm{EUR})\end{array}$ & $\mathrm{n}$ & $\begin{array}{l}\text { Retraites populaires, } \\
\text { Groupe mutuel }\end{array}$ \\
\hline Hannover & 26792 & $\mathrm{n}$ & 6000 EUR & 13000 EUR & n Hannover Airport \\
\hline Terst & $\mathrm{n}$ & $\mathrm{n}$ & $\mathrm{n}$ & $\mathrm{n}$ & n Generali \\
\hline Porto & 15000 & $n$ & 10000 EUR & 16000 EUR & 50000 EUR EDP - Energias de Portugal \\
\hline
\end{tabular}

Zdroj: Maratónsky klub Košice (2019), Association of Road Racing Statisticians (2019): International Running Calendar and runners' resources (2019), vlastné spracovanie; Vysvetlivky: sumy prepočitané a zaokrúhlené na menu euro podl'a prepočítavacieho kurzu Národnej banky Slovenska k februáru 2020, n-nezískané údaje 
V roku 2019 získal vít’az maratónu v Bostone 150000 \$, v New Yorku 100000 \$, v Tokiu 80000 \$, v Berlíne $50000 €$, v Londýne 39000 £, v Košiciach $20000 €$ (ak dosiahne čas lepší ako 2:07:00) a vít’az maratónu v Prahe $15000 €$. Výšku finančnej provízie určujú organizátori pre konkrétny ročník, pričom istú formu d’alšieho finančného zvýhodnenia môžu mat' domáci bežci, čo pripúšt’ajú aj pravidlá IAAF. S výnimkou 6 najlepších maratónov však nemožno povedat', že výška odmeny ovplyvňuje ranking.

Marketingovou stratégiou organizátorov je silná propagácia na báze reklamy, účasti známych osobností, pridávaním subdisciplín, charitatívnych akcií a pod. Maratón v Košiciach (v roku 2019 pod záštitou prezidentky, využíval aplikáciu od spoločnosti MYLAPS rovnako ako v Eindhovene, umiestnenie hudobných pódií, maratónsky vlak z Bratislavy do Košíc, viac ako 1000 usporiadatel'ov) vysielaný naživo v televízii (podmienka Silver label) má prispiet' k medializácii podujatia. Rok 2020 priniesol zrušenie mnohých maratónov. Maratón v Košiciach sa však tradične uskutočnil, čím si zachoval kontinuitu.

\section{Záver}

Najstarší maratón v Európe v Košiciach nie je napriek stabilne dobrej pozícií vo svetovom rebríčku v jednoduchej situácii, a to aj vd’aka rastúcej konkurencii. V 60. rokoch 20. storočia patril medzi vynikajúce podujatia, čo potvrdzovala účast' vrcholových bežcov. Aj ked' jeho umiestnenie v rebríčkoch hodnotenia za posledných 15 rokov značne fluktuovalo, udržiava si relatívne stabilnú pozíciu v systéme maratónov Európy. No je treba poukázat' na niekol'ko dopadov, resp. istých zmien na základe súčasného vývoja. Argumentovat' historickou dížkou trvania maratónu je už neadekvátne (aby Košice nedopadli ako Yonkers či Chiswick), lebo omnoho mladšie podujatia si vybudovali renomé aj za kratší čas. V našich geografických šírkach sa väčšina maratónov koná bud' na jar alebo na jeseň. Práve v mesiaci október (z aspektu stabilného teplotného vývoja priaznivé obdobie) sa konajú i maratóny v Lubl'ane či Eindhovene, ktoré disponujú lepšou geopolitickou polohou v rámci Európy. Iste hrá úlohu aj to, že v Košiciach sa doteraz nepodarilo dosiahnut’ čas pod úroveň 2:07:00, čo sa zase podarilo na podujatiach v Eindhovene, Prahe alebo vo Viedni.

Počtom bežcov je maratón v Košiciach porovnatel'ný s maratónmi v Padove, Lausanne, v rokoch 1996 - 2009 bol porovnatel'ný aj s Eindhovenom (tu však počet bežcov vzrástol za posledných 10 rokov o viac ako polovicu). Počtom bežcov na 1000 obyvatel'ov zaberá maratón v Košiciach pozíciu medzi L’ubl'anou a Eindhovenom. Na druhej strane, na maratónoch v Budapešti, Varšave alebo Viedni je počet bežcov na 1000 obyvatel'ov podstatne nižší ako v Košiciach. Dial'kové behy (kam patria aj maratóny) sú v súčasnosti vo svete doménou starších bežcov. Preto lepším indikátorom kvality je účast' najlepších bežcov (nielen z afrického kontinentu) a súčty napr. najlepších 10 časov, kde si Košice udržiavajú približne rovnakú pozíciu ako maratóny v Eindhovene, Viedni, Lubl'ane i Prahe. Vekový priemer bežcov rastie a niektoré maratóny v Európe (s výnimkou najlepšie hodnotených v rankingoch) sa stávajú podujatím skôr pre rekreačných bežcov umiestňujúcich sa v strednej a dolnej časti rebríčka, pričom priemerné výsledné časy sa zhoršujú. Na väčšine sledovaných maratónov v rokoch 1995 - 2019 (s výnimkou Budapešti a Varšavy) prevládajú vít’azi z Afriky. Výraznejšie medzinárodný charakter má maratón v Eindhovene či L'ubl'ane (to môže dokumentovat' ich vyššiu atraktivitu, ale aj lepšiu dopravnú dostupnost'). Košice majú podiel domácich bežcov takmer $79 \%$, hoci pred rokom 1990 vd'aka vel'kej účasti bežcov z "tábora socializmu" bol tento podiel nižší. Veková štruktúra účastníkov, zastúpenie podl'a pohlaví, účast' elitných bežcov sa mení v čase a odráža aj zvýšenú konkurenciu, priestorové rozšírenie maratónov, ekonomické a geopolitické zmeny. Miera diverzity maratónu v Košiciach klesá (miera diverzity 0,37 v roku 2019 oproti hodnote $0,57 \mathrm{v}$ roku 1980) a je nižšia ako v prípade Lubl'any $(0,70 \mathrm{v}$ roku 2019 oproti hodnote $0,05 \mathrm{v}$ roku 1996) či Eindhovenu (miera diverzity $0,57 \mathrm{v}$ roku 2019 oproti $0,66 \mathrm{v}$ roku 2011). V prípade Medzinárodného maratónu mieru je dlhodobo zastúpená výrazná skupina 
bežcov z krajín V4, Nemecka a Ukrajiny. Podl’a pohlavia dominujú muži, čo platí pre všetky sledované maratóny, avšak L'ubl'ana a Eindhoven vykazujú v porovnaní s Košicami o viac ako $5 \%$ vyšší podiel žien.

Organizátori maratónov sa rôznymi benefitmi či prémiami snažia na štartové pole dostat' aspoň niekol'ko elitných bežcov v snahe zvýšit' ranking maratónu. Maratóny v L'ubl'ane či Eindhovene v kontexte marketingu, sponzorov či informačnej dostupnosti dokázali pritiahnut' pozornost' a posilnit' svoje postavenie.

Košický maratón nemôže konkurovat' počtom účastníkov najmasovejším maratónom, ale konkuruje maratónom, ktoré v okolitých (porovnatel'ných) krajinách organizujú populačne väčšie mestá. Je pozoruhodné, ako dlho si MMM udržuje vysoké postavenie v rankingu IAAF. Významná čast' vysvetlenia úspechu spočíva v kombinácii jeho charakteristík: okrem dlhej tradície je to aj vysoký relatívny počet bežcov a divákov. V rámci vel'kostne porovnatel'ných miest jedine maratón v Lubl'ane ten košický výrazne prevyšuje. Maratón v L'ublane okrem lepšej geografickej polohy na styku západnej a stredovýchodnej Európy vykazuje aj podstatne vyššiu účast' v doplnkových disciplínach, vysoký podiel zahraničných účastníkov a celkovo väčší objem financií na odmeny. Hoci ide o mladé podujatie, môže byt' aj pre "starobylý" košický maratón inšpiráciou.

V roku 2020 sa bežal v poradí 97. ročník Medzinárodného maratónu mieru. Je podstatné, aby ho nedefinovala historická nostalgia ani utopická budúcnost'. Pozitívom je, že v kontexte svetovej pandémie sa maratón v roku 2020 uskutočnil so striktnými obmedzeniami ako jeden z mála maratónov.

\section{Zoznam literatúry}

ANDERSEN, J. J. 2019: Marathon Statistics 2019: Worldwide Marathon Statistics [cit. 201912-31]. Retrieved from: https://runrepeat.com/research-marathon-performance-acrossnations.

ASSOCIATION OF ROAD RACING STATISTICIANS 2019: Marathon Comparisons. [cit. 2019-11-25]. Retrieved from: https://arrs.run/RaceComp2.htm.

ASSOCIATION OF INTERNATIONAL MARATHONS AND DISTANCE RACE 2019: Race dates [cit. 2019-04-27]. Retrieved from: https://aims-worldrunning.org/calendar.html AUGUSTIN J. P. 1995: Sport, Géographie et Aménagement. Paris (Nathan).

BAČÍK, V., KLOBUČNÍK, M. 2013: History of Tour de France from the Geographical Point of View. Sport Science Review, 22(3-4), 255-277. DOI: https://doi.org/10.2478/ssr-2013-0013.

BAČÍK, V., KLOBUČNÍK, M. 2017: Stage finishes - Mapping the locations and results of Tour de France (1903 - 2016). Journal of Maps, (13)1, 82-89. DOI: https://doi.org/ 10.1080/1744 5647. 2017.1381193.

BAČÍK, V., KLOBUČNÍK, M., MIGNOT, J.-F. 2019: What made the tour successful? Competitive balance in the tour de France, 1947-2017. Sport in Society, 22(5), 1-19. DOI: https://doi.org/10.1080/17430437.2019.1621844.

BALE, J. 1982: Sport and Place: A Geography of Sport in England, Scotland and Wales. London (Hurst).

BALE, J. 1990: In the shadow of the stadium: Football grounds as urban nuissace. Geography, 75(4), 325-334.

BALE, J. 2003: Sports Geography. Second edition. London (Taylor\&Francise Library).

BAŠOVSKÝ, O., LAUKO, V. 1980: Úvod do regionálnej geografie. Bratislava (Slovenské pedagogické nakladatel'stvo).

BURLEY, T. 1966: A note of the geography of sport. The Professional Geographer, 14(1), 55-56. DOI: https://doi.org/10.1111/j.0033-0124.1962.00055.x. 
CIDELL, J. 2017: Running road races as transgressive event mobilities. Social \& Cultural Geography. 15(5), 571-583. DOI: https://doi.org/10.1080/14649365.2014.908236.

CITY POPULATION 2018: Population Statistics in Maps and Charts for all Countries in Europe [cit. 2019-08-07]. Retrieved from: https://www.citypopulation.de/Europe.html.

EUROPE MARATHON LIST 2018: European Marathons [cit. 2019-04-27]. Retrieved from: http://www.marathonrunnersdiary.com/races/europe-marathons-list.php.

EUROPE MARATHON CALENDAR 2018 - 2019: Marathons held in Europe [cit. 2019-1025]. Retrieved from: https://marathons.ahotu.com/calendar/marathon/europe.

HILDERBRAND, J. 1919: The Geography of Games. National Geographic Magazine, 32(2), 98-143.

HORVÁT, Z. 2011: Vývoj a súčasnost' bežeckých pretekov v meste Bratislava - bachelor thesis. Bratislava (Univerzita Komenského, Prírodovedecká fakulta).

IAAF 2019: Road Race Labels Regulation 2019 [cit. 2019-08-26]. Retrieved from: http://dt9guucc6nuua.cloudfront.net/competitioninfo/c2127e60-9aa4-40d9-bd90-43fd 7db3d607.pdf.

JONES, H., JAMES, J. 2012: Maratony nejvýznamnějši a nejvyhledávanější. Praha (Slovart).

KLOBUČNÍK, M., PLEŠIVČÁK, M., VRÁBEL', M. 2019: Football clubs' sport sperformance in the context of their market value and GDP in the European Union regions. Bulletin of Geography, Socio-economic Series, 45(45), 59-74. DOI: https://doi.org/10.2478/bog-2019-0024.

KONIAR, B., MATIA, B., ŠIMO, M. 2014: Medzinárodný maratón mieru - 90 rokov v príbehoch, faktoch a čislach. Košice (Progress Promotion).

KOREC, P. 2013: Pozícia Bratislavy a jej regiónu v regionálnej štruktúre Slovenska. In Buček, J., Korec, P. eds. Moderná humánna geografia mesta Bratislava: priestorové štruktúry, siete a procesy. Bratislava (Univerzita Komenského, Prírodovedecká fakulta), pp. 27-54.

KOŠČO, M. 2018: Významné športové podujatia a ich vplyv na dynamiku rozvoja svetových metropol - písomná práca k dizertačnej skúške. Bratislava (Univerzita Komenského, Prírodovedecká fakulta).

KOVÁČ, I. 2009: Organizovanie športových podujatí v urbánnom priestore. [cit. 2018-0122]. Retrieved from: http://www.sportcenter.sk/stranka/organizacia-sportovych-podujativ-urbannom-priestore.

LEHRMAN, H. 1940: The geographic origin of professional baseball players. Journal of Educational Research, 34(2), 130-138.

MAGUIRE, J. 2005: Power and Global Sport: Zones of prestige, emulation and resistence. London (Routledge).

MARATÓNSKY KLUB KOŠICE 2017: Výsledky Maratón [cit. 2018-08-21]. Retrieved from: https://www.kosicemarathon.com/maraton-2019/.

MARATÓNSKY KLUB KOŠICE 2019: Výsledky Maratón [cit. 2019-11-20]. Retrieved from: https://www.kosicemarathon.com/maraton-2019/.

QVISTRÖM, M. 2017: Competing geographies of recreational running: The case of the "jogging wave" in Sweden in the late 1970s. Health \& Place, 46, 351-357. DOI: https://doi.org/10.1016/j.healthplace.2016.12.002.

RAVENEL, L. 1998: Hiérarchies urbaines, hiérarchies sportives. L'Espace Géographique, 27(4), 339-348.

RECLUS, E. 1879: Géographie Universelle La terre et les hommes. L'Europe du Nord-Ouest. Librairie Hachette et Cie. Paris.

ROONEY, J. 1969: Up from the Mines and out from the prairies: some geographical implications of football in de US. Geographical Review, 59(4), 471-492. DOI: https://doi.org/ $10.2307 / 213858$. 
SLAVÍK, V., KOŠČO, M. 2015: Košice ako tradičná a významná metropola bežeckého maratónu. In Kulla, M., Novotný, L. eds. Zborník abstraktov zo 7. medzinárodného geografického kolokvia. Košice (Univerzita Pavla Jozefa Šafárika v Košiciach), p. 31.

SLAVÍK, V., KOŠČO, M. 2018: Vývoj TOP svetových a európskych maratónov. In Križan, F., Šveda, M. eds. Geografia na vzostupe? Bratislava (Univerzita Komenského v Bratislave), p. 93.

SLAVÍK, V., MIČIETOVÁ, E. 2002: Crossborder running races as a cross-border cooperation. Proceedings of the International Coloquy: State Border Reflection by Border Region Population of V4 States. Nitra (Constantine the Philosopher University), 72-78.

SLEPIČKOVÁ, I., SLEPIČKA P. 2012: Kde hledat počátky moderního sportu. Geografické rozhledy, 21(4), 2-5.

TOMEŠ, J. 2012: Sport a geografie I. Geografické rozhledy, 21(4), 6-9.

TOMEŠ, J. 2011 - 2012: Sport a geografie II. Geografické rozhledy, 21(4), 18-20.

TUŽINČIN, M. 2013: Mestské maratóny vo svetových metropolách - diplomová práca. Bratislava (Univerzita Komenského, Prírodovedecká fakulta).

WALTERSPIELER, M. 1982: Le football lorrain. L'espace géographiqued'un sport régional, Revue Géographique de l'Est, 22(3-4), 307-313.

WISE, N., KOHE, G. Z. 2018: Sports geography: new approaches, perspectives and directions. Sport and Society, 1-11. DOI: https://doi.org/10.1080/17430437.2018.1555209.

WORLD ATHLETICS 2019: Competition Performance Ranking [cit. 2019-07-25]. Retrieved from: https://www.worldathletics.org/records/competition-performance-rankings.

YOUNG, K. 2016: The 2015 Marathoners of the Year [cit. 2018-07-26]. Retrieved from: https://www.runnersworld.com/elite-runners/the-2015-marathoners-of-the-year.

ZUBRICZKÝ, G. 1996: Príspevok k analýze regionálnej diferenciácie Slovenska na príklade profesionálneho športu. Acta Facultatis Rerum Naturae Universitatis Comenianae, Geographica, 39, 247-253.

Príspevok bol pripravený s podporou projektu VEGA č.1/0745/16 „Autonómnost’, vzájomná závislost' a interakcie priestorových systémov“.

\section{Adresy autorov}

doc. RNDr. Vladimír Slavík, CSc.

Katedra ekonomickej a sociálnej geografie, demografie a územného rozvoja

Prírodovedecká fakulta, Univerzita Komenského v Bratislave

Mlynská dolina, Ilkovičova 6, 84215 Bratislava

Slovenská republika

vladimir.slavik@uniba.sk

RNDr. Milan Koščo, PhD.

Katedra ekonomickej a sociálnej geografie, demografie a územného rozvoja

Prírodovedecká fakulta, Univerzita Komenského v Bratislave

Mlynská dolina, Ilkovičova 6, 84215 Bratislava

Slovenská republika

kosco4@uniba.sk 